\title{
External shocks, internal shots: the geography of civil conflicts
}

\author{
Nicolas Berman \\ Graduate Institute of International Studies and CEPR \\ Mathieu Couttenier \\ University of Lausanne
}

\begin{abstract}
This paper uses detailed information on the latitude and longitude of conflict events within a set of Sub-Saharan African countries to study the impact of external income shocks on the likelihood of violence. We consider a number of external demand shocks faced by the country or the regions within countries - changes in the world demand of agricultural commodities, financial crises in the partner countries or changes in foreign trade policy - and combine these with information reflecting the natural level of trade openness of the location. We find that (i) within-country, the incidence, intensity and onset of conflicts are generally negatively and significantly correlated with income shocks within locations; (ii) this relationship is significantly weaker for the most remote locations, i.e those located away from the main seaports, (iii) at country-level, we cannot detect any significant effect of these shock on conflict incidence or onset; but (iv) large and longlasting shocks seem to affect the location of conflict outbreaks. In general, our results suggest that external income shocks are important determinants of the intensity and geography of conflicts within countries. However, conflicts tend to start in remote locations which are naturally less affected by foreign shocks, which might explain why these seem to have little effect on conflict onset at the country-level.
\end{abstract}

(C) The Authors. All rights reserved. No part of this paper may be reproduced without the permission of the authors. 


\title{
External shocks, internal shots: the geography of civil conflicts*
}

\author{
Nicolas Berman ${ }^{\dagger} \quad$ Mathieu CouttenieR ${ }^{\ddagger}$
}

September 10, 2012

\begin{abstract}
This paper uses detailed information on the latitude and longitude of conflict events within a set of Sub-Saharan African countries to study the impact of external income shocks on the likelihood of violence. We consider a number of external demand shocks faced by the country or the regions within countries - changes in the world demand of agricultural commodities, financial crises in the partner countries or changes in foreign trade policy - and combine these with information reflecting the natural level of trade openness of the location. We find that (i) within-country, the incidence, intensity and onset of conflicts are generally negatively and significantly correlated with income shocks within locations; (ii) this relationship is significantly weaker for the most remote locations, i.e those located away from the main seaports, (iii) at country-level, we cannot detect any significant effect of these shock on conflict incidence or onset; but (iv) large and longlasting shocks seem to affect the location of conflict outbreaks. In general, our results suggest that external income shocks are important determinants of the intensity and geography of conflicts within countries. However, conflicts tend to start in remote locations which are naturally less affected by foreign shocks, which might explain why these seem to have little effect on conflict onset at the country-level.
\end{abstract}

JEL classification: D74, F15, O13, Q17

Keywords: conflict, income shock, civil war

\footnotetext{
*We thank Jean-Louis Arcand, Emmanuel Milet, Mathias Thoenig, Vincent Vicard and seminar participants at PSE and Namur for useful comments and discussions.

${ }^{\dagger}$ Graduate Institute of International and Development Studies (IHEID) and CEPR. Address: Case Postale 136, CH - 1211, Geneva 21 - Switzerland. Tel: (0041) 22908 5935. E-mail: nicolas.berman@graduateinstitute.ch.

${ }_{\ddagger}^{\ddagger}$ University of Lausanne. Quartier UNIL-Dorigny Bâtiment Extranef 1015 Lausanne. E-mail: mathieu.couttenier@unil.ch
} 


\section{Introduction}

The effect of income shocks on the probability of civil conflict has been at the core of intense debates among economists and political scientists over the last decade. A particular attention has been given to the effect of commodity price variations, taken as a proxy for exogenous external income shocks (Besley and Persson, 2008, Brückner and Ciccone, 2010, Fearon, 2005). At the country-level, the results are mixed at the very least. ${ }^{1}$ Recently, Bazzi and Blattman (2011) have challenged most of the findings found by the literature, arguing that a significant relationship between commodity prices and conflict incidence can only be detected using very specific samples, definitions of civil conflicts or estimators. On the other hand, the causal relationship seems more robust at the micro-level (e.g. Dube and Vargas, 2011). However, even when income shocks are found to significantly affect conflict probability, the identification of the precise transmission channel remains problematic.

This paper uses PRIO/ACLED data containing detailed information on the location of conflicts within a set of Sub-Saharan African (SSA) countries to study the effect of external income shocks on the likelihood of violence. Our data contain several countries, and the precise latitude and longitude of violent events within each of them. We have two main objectives. First, the different dimensions of our data allows us to study the effect of external shocks both within and across countries, and to try to reconcile the seemingly contradictory results found by microand macro-level studies. Second, we discuss the plausibility of various channels through which external income shocks might affect conflict outbreak and intensity.

We propose a number of alternative ways to identify exogenous income shocks through international trade patterns. First, we improve the usual measures of (temporary) commodity shocks by constructing a region-specific measure of agricultural specialization. More precisely, we consider changes in the world demand for the agricultural commodities produced by the regions within the countries, removing the usual assumption that specialization is similar across locations. Second, we go further the existing literature by also considering a number of longlasting external demand shocks. We consider two additional shocks: (i) the number of banking crises in the country's trading partners (weighted by the share of each partner in the country's total exports); (ii) changes in foreign trade policy through the entry into force of the African Growth Opportunity Act (AGOA), which provided free access to the US market to a number of

\footnotetext{
${ }^{1}$ Among the most recent contributions, Besley and Persson, 2008 find a positive relationship between income shocks and civil war incidence, while Brückner and Ciccone, 2010 find the opposite.
} 
SSA countries after 2000 for a wide range of products. We combine these shocks with locationspecific information reflecting their "natural" level of trade openness, proxied by the relative distance to the nearest major seaport. Our study therefore differs from the existing literature in its level of analysis (both across and within countries) and scope (i.e. types of shocks). From an identification perspective, combining temporary and long-lasting external shocks with location-specific information also ensures that we are capturing different aspects of exogenous changes in income. Moreover, the various dimensions of our data allow us to study how external shocks affect the geography and intensity of conflict within countries.

At the micro-level, we find that the incidence, intensity and onset of conflicts are generally negatively and significantly correlated with income shocks within locations. More precisely, a negative external income shock increases the probability and intensity of conflict on average across locations within countries. Second and importantly, the relationship between external income shocks and conflict is significantly weaker in naturally less open locations, i.e when one moves away from the seaports. This clearly suggests that we are identifying the effect of exogenous shocks related to international trade, which are less likely to affect the most remote regions. Importantly, these results are observed for our three external shocks, and remain robust to the use of various estimation techniques and to the inclusion of additional location-specific controls, among which the location's GDP, distance to the capital city, to international border or to natural resource fields.

The fact that external income shocks affect the likelihood of conflict on average within locations implies that they affect the intensity of conflict at the country-level. However, we do not detect any significant effect on conflict incidence or onset at the country-level, whatever the considered income shock. This (lack of) result is consistent with Bazzi and Blattman (2011). We show that we can partly reconcile the apparent contradiction between our microand macro-level findings by noting that conflicts tend to start on average in relatively remote locations, which are by definition more inward-oriented and therefore less affected by external shocks. Finally, large, long-lasting shocks such as foreign banking crises or the AGOA seem to have an effect on the location of conflict outbreak at the country level - contrary to commodity shocks which only have an impact on the intensity of ongoing conflicts.

Our findings yield at least two important conclusions. First in terms of the predictions of the workhorse models of conflict, which are a priori ambiguous: on the one hand, a larger 
income might decrease the risk of conflict, either by reducing the individuals' opportunity cost of insurrection or by increasing the capacity of the state to prevent rebelion (e.g. Fearon and Laitin, 2003); on the other hand, positive income shocks might impact positively the likelihood of conflict by increasing the value of resources to fight over. Our results clearly point to the first group of predictions, and more specifically to the opportunity cost mechanism. The state capacity should indeed be more prevalent in the regions located close to the political center, i.e. the capital city (Buhaug, 2010). We do not find support for this hypothesis. Second, our results suggest that external income shocks are important to understand the geography and intensity of ongoing conflicts, but that they are probably not the main determinants of the outbreak of a conflict at the country-level. If the opportunity cost story is relevant, it is therefore mainly through the escalation and spatial evolution of ongoing conflicts, rather than through the outbreak of new ones. More generally, our results contribute to the literature on the impact of international trade on civil conflicts (Barbieri and Reuveny, 2005, Jha, 2008, Martin et al., 2008). In particular, we show that trade openness might influence importantly the geography of conflicts within countries.

Our paper i related to the literature documenting the effect of income shocks at the microlevel. The limitations of the cross-country studies, as well as the availability of more geographically detailed data, has recently pushed the researchers to move toward a more disaggregated approach. Buhaug et al. (2011) find that within countries, conflicts are more likely to erupt in the poorest regions. Buhaug (2010) argues that civil wars locate further away from the capital in more powerful political regimes. ${ }^{2}$ The impact of income or more generally economic shocks on the incidence of conflict or riots within states have been studied by a number of recent country-specific studies. Using data on Colombian municipalities, Dube and Vargas (2011) find evidence in favor of both the opportunity costs and state as prize theories. More precisely, they show that positive commodity price shocks decreases the likelihood of conflicts in the case of coffee (a labor-intensive commodity) but raises the probability of conflict for oil (a capital intensive commodity). Following Miguel et al. (2004), Hidalgo et al. (2010) use data on Brazilian municipalities and find that favorable economic shocks, instrumented by rainfall ${ }^{3}$, affect positively the number of land invasions within municipalities. This is also the case for Bohlken

\footnotetext{
${ }^{2}$ These two papers use UCDP/PRIO data on the location the first reported violent event of conflicts for a number of countries. They do not consider income shocks or the geography of conflicts afterwards.

${ }^{3} \mathrm{~A}$ large controversy on the robustness of this instrumentation exists since the seminal paper of Miguel et al. (2004) - see Couttenier and Soubeyran (2010) for a literature review.
} 
and Sergenti (2010) in the case of Hindu-Muslim riots in India. Nillesen and Verwimp (2009) find an effect of rainfall, but no significant effect of commodity prices on rebel recruitment in Burundi using village-level data. Finally, Jia (2011) finds that droughts increased the probability of peasant revolts in China using historical data over the 1470-1990 period. By focusing on a specific country, this strand of research is able to identify very precisely the effect of income shocks on conflicts through individuals' behavior. The generalization of these results is however made difficult by the potential selection bias inherent to any country-case study. Our paper is a first attempt to make a link between macro, cross-country studies and micro, country-case ones, through the consideration of both within and between countries variations.

In the next section, we discuss the theoretical mechanisms that generate predictions about the impact of income on conflict. Section III describes the data and the computation of income shocks. Section IV presents the empirical methodology. Section V and VI present our main results on the effect of external income shocks on conflict within and across countries. We discuss the interpretation and relation of our results with the existing literature in section VII. The last section concludes.

\section{Income shocks and conflicts}

Theoretical literature on the roots of civil conflicts generally makes a distinction between "capacity" and "opportunity" related causes of conflicts. Various theoretical mechanisms predict an effect of economic shocks on conflicts. This section presents a short survey of the literature which aims at guiding our empirical strategy in the next sections. ${ }^{4}$

The theoretically ambiguous effect of economic shocks on conflict can be understood using contest theories, in which the probability of conflict depends on a trade-off between production and expropriation. In these models (Haavelmo, 1954, and, Hirshleifer, 1989 among others), appropriation is modeled as a contest success function in which the probability of winning depends on the fighting technology, which is defined broadly and may include for instance the geographical conditions. In case of success, the individuals appropriate the opponent's economic production, which represents an opportunity to gain. But, as shown by Grossman

\footnotetext{
${ }^{4}$ For more complete surveys on the theories of conflict, see Garfinkel and Skaperdas (2007) or Blattman and Miguel (2010).
} 
$(1991)^{5}$, individual participation depends also on the opportunity cost of fighting, which is itself a positive function of income. The higher the income, the lower the incentives to fight. Similarly, a negative income shock therefore increase the individuals' incentive to fight by reducing this opportunity cost.

However, as in these models the winning party appropriate the resources of the opponents, the effect of an income shock is ambiguous, as shown formally by Fearon $(2006)^{6}$ : in the case of a negative shock, the probability of conflict might as well decrease, as the "prize" (the resources that can be appropriated by exerting violence) is lower. ${ }^{7}$

A way to distinguish between these two effects has been proposed by Dal Bó and Dal Bó (2011). In their two-sector model, income shocks have an opposite effect depending on whether they affect the capital- or the labor-intensive sectors. In the first case, a larger income (due for instance to a rise in the world price of the good) increases conflict probability, as it increases the value of controlling the state but has a negligible effect on wages. The opposite is true for the labor-intensive sector: the opportunity cost effect dominates, and conflict becomes less likely. Evidence in favor of these predictions have been found by Dube and Vargas (2011) using Colombian data and world changes in the commodity price of coffee (labor intensive) versus oil (capital intensive).

Using a dynamic bargaining model, Chassang and Padro-i Miquel (2009) show that the probability of conflict is more likely to increase when the economy is hit by transitory negative income shocks. The intuition is that individuals do not fight for current returns, but rather for the discounted present value of victory. Transitory negative income shocks decrease the opportunity cost of fighting but leave this discounted value unchanged, therefore increasing the likelihood of conflict.

Importantly, a negative correlation between (positive) income shocks and conflict incidence does not provide a definitive test of the opportunity cost mechanism. Conflict probability might as well decrease when the country experiences "good" shocks because they provide the state with the financial means to strengthen the control of opponents or buy off opposition (see Fearon and Laitin, 2003). Intuitively, this "state capacity" effect should be more prevalent in regions located close to the political center of the country, i.e. the capital city. This would be

\footnotetext{
${ }^{5}$ See also Besley and Persson (2011).

${ }^{6}$ Fearon uses a contest model. See also Chassang and Padro-i Miquel (2009) for a similar result using a bargaining approach.

${ }^{7}$ For empirical evidence, see Cotet and Tsui (2010), Lei and Michaels (2011) or Ross (2006).
} 
consistent with Buhaug (2010), who finds that conflicts are more likely to be located far from the capital in countries with more powerful regimes.

As emphasized by Cederman et al. (2011), inequality is another potential determinant of civil conflict. A positive income shock might therefore have an ambiguous effect, depending on how it affects income inequality. This argument is particularly relevant to the case of foreign shocks, which may affect heterogeneously income across regions within countries. We indeed find some evidence that large positive external shocks increase conflict intensity in the most remote regions.

\section{Data}

Our main objective is to study the economic determinants of conflicts both within and across countries. We therefore need data on (i) the location on conflict events within countries; (ii) external shocks potentially affecting conflict through income; (iii) location-specific characteristics influencing the way in which each location might respond to these external income shocks.

\subsection{Conflict data}

We use the Armed Conflict and Event dataset (ACLED) constructed by UCDP $/ \mathrm{PRIO}^{8}$, which contains detailed conflict data by location, for a subset of African countries. A "location" is defined by a given latitude and longitude. The unit of observation is the event. Our data contains the date (precise day most of the time), longitude and latitude of conflicts events within each country. It also includes some information on the type of event (violent, non violent) and issue (rebel or government gains territory) of the conflict. We aggregate the data by year and location, therefore ending up with three main variables that we use as dependent variables in our empirical analysis: a dummy which equals one if at least one conflict happened in the location during the year (which we interpret as location-specific conflict incidence), the number of conflicts that did occur in the location during the year (conflict intensity) and the outbreak of civil conflict (conflict onset) which is coded 1 for the first year of the civil conflict in the location, 0 for each year of peace and set to missing from the second year to the last year of the civil conflict.

\footnotetext{
${ }^{8}$ This dataset can be found on the following website: http://www.prio.no/CSCW/Datasets/ArmedConflict/Armed-Conflict-Location-and-Event-Data/
} 
The raw dataset contains 13 countries and covers a long time period (1960-2005). We drop the countries with less than ten observations to end up with 8 countries: Angola, Burundi, Democratic Republic of Congo, Congo, Liberia, Sudan, Sierra Leone, and Uganda. We concentrate on the 1980-2005 period due to data availability for the computation of income shocks. All these countries have known civil war episodes over the period of study. Our final sample includes 1054 locations, and an average of 130 locations by country (and a median of 100). ${ }^{9}$ Our sample contains only conflicts reaching at least 25 battle-related deaths per year, and is therefore comparable with the country-level data commonly used in the literature. ${ }^{10}$ Figure 2 shows the number of locations with at least one event, by year. Figures 3 and 4 show the locations of conflict events, conflict outbreaks and of the major seaports for each country of our sample. It is apparent that conflict tend to starts in remote locations in the case of the Democratic Republic of Congo, Liberia or Sudan. Table 8 in appendix contains some descriptive statistics. The sample mean for the conflict incidence variable is low at $7 \%$. Conditioning on observing a conflict during the year, the mean number of conflict events is only slightly above 1 (1.39). Note that the maximum number of conflict events observed in a given location during a given year is 16 .

We also use an alternative dataset developed also by ACLED to check the robustness of our results. ${ }^{11}$ It contains most African countries, but is limited to the 1997-2010 period. For consistency, we concentrate on the countries in which at least one civil conflict occurred over the period according to the UCDP/PRIO definition. ${ }^{12}$ This dataset records all political violence including violence against civilians, rioting and protesting within and outside a civil war, without specifying a battle-related deaths threshold. The broader definition of civil conflict makes the comparison with the country-level literature difficult. We however show that our micro-level results are qualitatively similar using either dataset.

\footnotetext{
${ }^{9}$ We run estimations at the location-level, therefore including only the locations which will endure a conflict event at some point during our period of study. As shown later, our results are however robust to aggregating our location-specific data by $1 \times 1$ degrees cells.

${ }^{10} \mathrm{UCDP} / \mathrm{PRIO}$ defines an armed conflict as "a contested incompatibility that concerns government or territory or both where the use of armed force between two parties results in at least 25 battle-related deaths" (Gleditsch et al., 2002: 618-619)

${ }^{11}$ http://www.acleddata.com/

${ }^{12}$ These are the same countries as our benchmark dataset, plus Rwanda, Chad and Somalia. We drop Somalia as its recorded international trade flows are close to zero over the period.
} 


\subsection{Income shocks}

Our identification strategy rests upon the use of both country-wide income shocks and locationspecific characteristics. Our first objective is to study the effects of external (i.e. foreign) shocks on the incidence, onset or intensity of conflict in a given location within a given country. All these shocks are based on variations in the foreign demand for the goods produced by the country or region to which the location belongs. We focus on three different types of foreign shocks. While they are all supposed to capture exogenous variations in foreign demand for the goods exported by the country / location, they are different in their scope and nature. In particular, while the first shock (based on the world demand for agricultural commodities) can arguably be considered as temporary and limited in scope, our two last (based on financial crises and permanent changes in trade policy) are larger and longer-lasting. Therefore, considering different shocks allows to check the robustness of the results, but also to discuss the way in which income shocks affect the incidence of conflicts. Descriptive statistics on each of the income shocks variables are provided in Table 8 in the appendix.

Temporary Shock: Agricultural commodities. As mentioned earlier, a number of papers have tried to identify the effect of commodity shocks on the likelihood of conflict across countries (e.g. Fearon, 2005, Bazzi and Blattman, 2011, Brückner and Ciccone, 2010, Besley and Persson, 2008). ${ }^{13}$ Little work has been done within country (with the notable exception of Dube and Vargas, 2011). We combine our conflict data with FAO Agro-maps information to obtain a region-specific measure of agricultural specialization. The FAO Agro-maps data contains information on the volume of production of different agricultural commodities at the subnational level, for a number of years. ${ }^{14}$ For each commodity, we obtain the value of production by multiplying the volume provided by the FAO by unit values computed from UN-Comtrade data. We consider here 70 commodities such as bananas, cocoa, coffee or tomatoes (see table 9 for an exhaustive list). Then we compute the average share of each commodity in the total agricultural production value of the region. ${ }^{15}$ Finally, we combine this data with the world total imports of each commodity from UN-Comtrade, to end up with a time-varying, region-specific

\footnotetext{
${ }^{13}$ See also Deaton (1999).

${ }^{14}$ Agro-maps is using the Second Administrative Level Boundaries (SALB) defined by the UN based on national administrative units. Here we focus on the years 1989-2005 to be able to match the product classification with HS6 trade data from UN-COMTRADE.

${ }^{15}$ We also tried to replace $\alpha_{c r}$ by a dummy which equals 1 if the region $r$ has produced the commodity $c$ at least one year over the period. The results, available upon request, remained largely unchanged.
} 
measure of external demand for the commodities produced by the region ${ }^{16}$ :

$$
\mathrm{WD}_{r t}=\sum_{c} \alpha_{c r} \times M_{c t}^{W}
$$

where $\alpha_{c r}$ is the average share of agricultural commodity $c$ in region $r$, and $M_{c t}^{W}$ are the world imports of commodity $c$ in year $t$.

Changes in the demand for agricultural commodities are generally modest, and can be considered as temporary. Our second type of external demand shocks is based on large foreign events, such as financial crises or significant changes in trade policy, which might affect domestic income more importantly, and more durably.

Long-lasting shock \# I: Banking crises. Our next measure of income shock is the exposure of the country to financial crises in the rest of the world. Financial crises destroy trade ${ }^{17}$, and are arguably exogenous to trading partners' economic or political situation (especially if the trading partner is a small African economy). Importantly, they typically last in general several years and have persistent effects on imports (Abiad et al., 2011), especially when the origin country is in Sub-Saharan Africa (Berman and Martin, 2012). For each country $i$, we compute the following time-varying indicator:

$$
\text { Crisis exposure }_{i t}=\sum_{j} \omega_{i j} \times C_{j t}
$$

where $j$ is the destination country and $t$ is the year. $\omega_{i j}$ is the average share of destination $j$ in country $i$ 's total exports over the 1980-2009 period, and $C_{j t}$ is a dummy which equals 1 if destination $j$ experienced a banking crisis during year $t$. The trade data comes from the IMF Direction of Trade Statistics (DOTS), and the crisis data from Reinhart and Rogoff $(2011)^{18}$. The Crisis exposure ${ }_{i t}$ variable therefore represents the number of banking crises in the destinations served by country $i$, weighted by the average share of each destination in its total exports. It represents a global demand shock on all the goods exported by the country.

\footnotetext{
${ }^{16}$ Considering world demand instead of world prices allows us to consider a wider range of commodities, including commodities which do not have a world price. We will however check that our results are robust to the use of commodity price variations using the data from Bazzi and Blattman (2011) - see Table 10.

${ }^{17}$ See for instance Abiad et al. (2011) for a long-term perspective, and the literature on the recent trade collapse summarized in Baldwin (2009).

${ }^{18}$ Reinhart and Rogoff (2011) define a crisis as (1) "bank runs that lead to the closure, merging, or takeover by the public sector of one or more financial institutions; and (2) if there are no runs, the closure, merging, takeover, or large-scale government assistance of an important financial institution (or group of institutions), that marks the start of a string of similar outcomes for other financial institutions."
} 
As this variable is based on trade shares, we interpret it as a real shock on demand for the country's produced goods, despite the fact that we are looking at a financial event. We consider indeed as unlikely the possibility that the shock affects conflict through the country's financial system: even though the geographical distribution of international financial linkages is closely related to trade in goods (see for instance Aviat and Coeurdacier, 2007), Sub-Saharan countries' financial systems are arguably too small and closed to generate such an effect.

Long-lasting shock \# II: African Growth Opportunity Act. Starting in the early 2000s, the US granted free access to its market to a number of African countries, for a large range of products. The year in which these preferences were granted depends on the country. ${ }^{19}$ As shown by Frazer and Biesebroeck (2010), the AGOA had a positive and significant effect on these countries' exports. We use a dummy $\left(A_{i t}\right)$ which equals 1 if the country entered the AGOA in year $t$. This variable is possibly less exogenous that the previous ones. A country becomes eligible to the AGOA only when it meets certain conditions, among which political stability may play a role (although it does not appear explicitly in the list of criteria defined by the agreement). To ensure that we are focusing on a shock that is exogenous, we refine the variable. First, as not all products are eligible to the AGOA, countries should be affected heterogeneously depending on their exposure to AGOA-eligible products, and depending on how much they trade with the US. We define the "exposure to AGOA" as follows:

$$
\operatorname{Exp}_{i t}^{A G O A, 1}=\beta_{i p}^{U S} \times A_{i t}
$$

where $\beta_{i p}$ is the average share of total exports of country $i$ in AGOA-eligible products to the US before the AGOA enters into force (from 1995 to the year in which the preferences are granted to the country). This variable does not only reflect the fact that a country entered the AGOA, but also the extent to which it is likely to be affected ex-post due to its ex-ante specialization. This variable is more exogenous to political conditions. We also interact $A_{i t}$ with the distance between the country's main seaport (see below for a discussion of the seaport data) and the US (New York City):

\footnotetext{
${ }^{19}$ For the list of eligible countries, products and dates in which the preferences were granted, see: http://www.agoa.gov/AGOAEligibility/index.asp. We do not consider other unilateral liberalization initiatives such as Everything but Arms in the EU, as these are generally granting free market access for the entire range of products, which limits the scope for identification. The countries included in our estimations entered the AGOA in 2000 (Chad, Congo, Rwanda, Uganda), 2002 (Sierra Leone), 2003 (Democratic Republic of Congo), 2004 (Angola) and 2006 (Burundi, Liberia).
} 


$$
\operatorname{Exp}_{i t}^{A G O A, 2}=\operatorname{distance}_{i}^{U S} \times A_{i t}
$$

We expect a country to be less affected by the AGOA if is it located further away from the US. This again ensures that we are identifying an exogenous shock: if a country's eligibility to the AGOA can plausibly be affected by political conditions, there is a priori no reason to believe that this bias is differently distributed according to the distance of the country to the US.

\subsection{Natural openness}

All the shocks described above are based on variations in the foreign demand for the goods produced by the country or region to which the location belongs. As these are income shocks based on international trade, we expect them to have a lower impact on the locations that are naturally less open, i.e. on the locations for which trade costs are higher. Income in these locations might be primarily driven by self-consumption and disconnected from the world market.

We therefore construct measures of relative natural trade openness which we then interact with our external income shocks. This has first an identification purpose: to ensure that we are identifying the effect of (exogenous) external foreign demand shocks, and not of some other (e.g. internal) shocks that may be correlated with them. Beyond that, it allows to create heterogeneity and to study how external income shocks affect the geography of conflicts within each country, which to our knowledge has not been done so far. This identification strategy also help us to reconcile the divergent results found by the cross-country and within-country literatures.

For each location, we compute the distance (in kilometers) to the closest major seaport. ${ }^{20}$ We retain the main ports of each country with a maximum draft of at least 10 meters. Note that the closest seaport is not necessarily located in the same country, as some countries are landlocked, or some locations closer to a foreign port. ${ }^{21}$ As we want to identify heterogeneous effects within, and not across countries, we take the ratio between this distance and the largest

\footnotetext{
${ }^{20}$ The data on major seaports is from http://www.e-ships.net/ports.php.

${ }^{21}$ Restricting our analysis to port located in the same country (therefore excluding landlocked countries) does not alter our results. Similarly, our findings are robust to considering seaports with a maximum draft larger or equal to 12.5 meters or 15 meters. Results are available upon request.
} 
distance observed by country. Using "relative distance" ensures that we are not identifying the effect of some country-specific omitted variables that affect conflict likelihood and are correlated with the remoteness of the country.

For robustness purposes, we also check the results using two alternative measures of "remoteness". First, we consider the simple distance between each location and the nearest seaport (not in relative terms with respect to the maximum distance). Second, we use the average "roughness" of the terrain around the location as an alternative measure of openness. This variable, which takes values between 0 to 1 , is taken from the G-Econ dataset. ${ }^{22}$ We interpret it as an alternative measure of remoteness of the location.

To ensure that we are indeed identifying the effect of trade openness, and not of economic activity in general, we have also computed the relative distance of the location to the capital city of the country (again relative to the highest distance observed by country). Controlling for distance to the capital city is also important for the interpretation of our results: a negative correlation between our income shocks and conflict probability can either be interpreted as evidence of an opportunity cost effect or of a state capacity effect. In the latter case, however, we would expect the correlation to be larger for regions located close from the political center of the country (i.e. the capital, see Buhaug, 2010). As shown later, our results do not support this hypothesis, therefore suggesting that we are indeed identifying an opportunity cost mechanism. Descriptive statistics about these various distance measures are provided in Table 8 in the appendix.

\subsection{Other data}

We also control for a number of location-specific geographical or economic characteristics, such as distance to natural resource fields or GDP, which we now describe in details.

G-Econ. We add to our dataset information at a slightly more aggregated level from GEcon. G-Econ data, developed by Nordhaus et al. (2006), contains geographical information (roughness, elevation, vegetation, etc.) as well as economic indicators (GDP, population available every five years from 1990 to 2005) for most countries in the world, divided by 1 $\times 1$ degree grid cells. We assign each location to the grid cell to which it belongs. Among

\footnotetext{
${ }^{22}$ As explained below, the G-econ data contains geographical and economic variables at a geographically disaggregated level, i.e. by $1 \times 1$ degree grid cells. For a precise description of the computation of the roughness measure, see http://gecon.yale.edu/sites/default/files/envdat.pdf.
} 
others, this allows us to control for the GDP of the area. Note that, as shown in section 5.4, we have tried to run our estimations at this level of geographical aggregation, and that our results remained similar.

Natural resources. We compute the distance from each location to the closest diamond and oil fields. The latitudes and longitudes of these fields of natural resources come from PRIO. ${ }^{23}$

\section{Empirical methodology}

\subsection{Baseline specification: Micro Level}

Our objective is to study the way in which foreign demand shocks affects the likelihood and intensity of conflict within countries. Let us denote by $l$ a specific location, $i$ a country and $t$ a year. In general, we want to estimate a specification of the form:

$$
\text { Conflict }_{l, t}=\beta \text { shock }_{i, t}+\gamma \operatorname{shock}_{i, t} \times \text { remoteness }_{l}+\eta_{t}+\mu_{l}+\varepsilon_{l, t}
$$

where Conflict ${ }_{l, t}$ is a variable that captures the incidence, onset or intensity of a conflict in a given location ${ }^{24}$, during a given year. shock $_{i, t}$ denotes a shock affecting the external demand for the goods produced by country $i$ or location $l$ : alternatively (i) the world demand for agricultural commodities produced by the region (equation (1) - in this case the variable is location-specific, i.e. $\operatorname{shock}_{l, t}$ ); (ii) the exposure to banking crises (equation (2)), (iii) or the exposure to the AGOA (equations (3) and (4)). Finally, remoteness $l$ represents our inverse measure of the "natural trade openness" of the location. In our baseline estimations, this variable is the distance of location $l$ from the closest seaport divided by the maximum distance of a location to the closest seaport, computed by country.

Finally, in all estimations we control for time dummies $\eta_{t}$ and location-specific characteristics $\mu_{l}$. The latter capture time-invariant characteristics that may affect the average likelihood of conflict in a given location, e.g. the distance to the closest port, to the capital, to natural resources, or the region's roughness. In a second step, we show that our results are robust

\footnotetext{
${ }^{23} \mathrm{http}$ ://www.prio.no/CSCW/Datasets/Geographical-and-Resource/Diamond-Resources/

${ }^{24}$ As shown later, our results are robust to aggregating our data and running our estimations at the $1 \times 1$ degrees cells level.
} 
to the inclusion of additional interactions terms between $\operatorname{shock}_{i, t}$ and other location-specific characteristics.

The sign of $\beta$ is theoretically ambiguous, as mentioned in section 2. Assume that an increase of $\operatorname{shock}_{i, t}$ represents an exogenous increase in country $i$ 's income (e.g. higher demand for the country's products). According to the state-as-prize theory, this larger income should increase the likelihood of conflict; $\beta$ should be positive in this case. On the contrary, the opportunity cost theory predicts that this larger income should increase the opportunity cost of fighting, therefore reducing the risk of conflict; $\beta$ should be negative. But, as underlined in section 2, a negative estimate of $\beta$ can be also interpreted as evidence in favor of the state capacity channel. The increase in country $i$ 's income provides the state with the financial means to strengthen the control of opponents or buy off opposition. We provide two tests suggesting that the opportunity cost is a more relevant explanation: (i) the size of our effect does not depend on the distance to the capital city; (ii) our shock variables are indeed correlated with changes in GDP per capita at the regional level, the less so as remoteness increases.

Finally, we expect $\beta$ and $\gamma$ to be of opposite signs: the most remote locations face larger trade costs, are more inward-oriented, and should be less relatively affected by foreign income shocks. These shocks should therefore influence the geography of conflicts.

\subsection{Econometric issues}

Conflict incidence and onset. We assess the effect of external shocks on both the incidence and onset of conflict. We first estimate a probabilistic model of the form:

$$
\operatorname{Pr}\left(\text { Conflict }_{l, t}>0\right)=\beta_{1} \text { shock }_{i, t}+\gamma_{1} \text { shock }_{i, t} \times \text { remoteness }_{l}+\eta_{t}+\mu_{l}+\varepsilon_{l, t}
$$

where the dependent variable is conflict incidence, i.e. a dummy taking the value 1 if location $l$ experienced a conflict during year $t$. We study also the onset of a civil conflict by estimating equation (6) conditional on Conflict $_{l, t-1}=0 .{ }^{25}$

The cleaner way to estimate this specification is through a conditional logit estimator that accounts for all location-specific time-invariant unobserved characteristics. This is our preferred estimator. However, due to the difficulty to interpret the size of the estimated coefficients in this case, we systematically show the results obtained with a linear (OLS) estimator with location

\footnotetext{
${ }^{25}$ This variable is coded as "missing" for ongoing conflicts.
} 
fixed effects.

Conflict intensity. As a measure of conflict intensity, we use the number of conflict events ${ }^{26}$ in location $l$ during the calendar year $t, N_{l, t}^{c}$, as a dependent variable and estimate:

$$
N_{l, t}^{c}=\beta_{1} \operatorname{shock}_{i, t}+\gamma_{1} \operatorname{shock}_{i, t} \times \operatorname{remoteness}_{l}+\eta_{t}+\mu_{l}+\varepsilon_{l, t}
$$

As $N_{l, t}^{c}$ is a count variable, the use of fixed-effects Pseudo-Maximum Likelihood Poisson (PPML) estimator is appropriate. Again, we replicate the results using a linear estimator.

In all estimations, we use robust standard errors, clustered at the location level. Finally, we control for temporal trends in the causes of conflicts (Miguel et al., 2004, Bazzi and Blattman, 2011) and we systematically check that the our results are robust to the inclusion of countryspecific time trends (for both conflict probability and intensity).

Conflict outbreak location. The above specifications provide information on the effect of external income shocks on the likelihood or intensity of conflict within a given location in general, i.e. not conditioning on whether a conflict is already taking place elsewhere in the country. It might be the case, however, that income shocks have an effect on the way in which conflicts evolve within countries over time, without being necessarily at the source of the outbreak of the event. In order to better understand whether external income shocks influence the outbreak of a civil conflict we estimate a variant of equation (6) where we condition the conflict onset at the country level, i.e.:

$$
\operatorname{Pr}\left(\text { Conflict }_{l, t}>0 \mid \text { Conflict }_{i, t-1}=0\right)=\beta_{1} \operatorname{shock}_{i, t}+\gamma_{1} \operatorname{shock}_{i, t} \times \operatorname{remoteness}_{l}+\eta_{t}+\mu_{l}+\varepsilon_{l, t}
$$

where Conflict $_{i, t-1}$ equals 1 if at least one violent event is recorded in country $i$ during year $t-1$. This specification allows us to study whether external income shocks affect the location of conflicts when a civil conflict starts, and, in general, whether these shocks are significant determinants of conflicts outbreak at the country-level.

\footnotetext{
${ }^{26}$ We do not have information on the number of death by event, contrary to the country-level literature.
} 


\subsection{Relation with the cross-country literature: Macro Level}

As we are using location fixed effects, our results should be interpreted as the effect of external shocks within a given location, over time. By studying how the probability of conflict varies for each location, we are implicitly studying the intensity of conflict at the country-level: an increase in the probability of conflict on average across locations implies a magnification of conflict intensity at the country-level. To ease the comparison between our results and those of the existing literature (e.g. Bazzi and Blattman, 2011), we perform a number of additional estimations at the country-level. More precisely, we first study the effect of our various income shocks on conflict onset, incidence or intensity at the country-level, i.e. estimate a specification of the form:

$$
\text { Conflict }_{i, t}=\beta \text { shock }_{i, t}+\eta_{t}+\mu_{i}+\varepsilon_{i, t}
$$

where Conflict $_{i, t}$ denotes conflict incidence (a dummy which equals 1 if at least one violent event was recorded during year $t$ in country $i$ ), onset (a dummy which equals 1 if at least one violent event was recorded during year $t$ in country $i$, but no violent event was recorded in $t-1)^{27}$ or intensity (number of locations with violent events, or total number of violent events observed in country $i$ during year $t$ ). Finally, in all estimations we include time dummies $\eta_{t}$, country-specific time-trends, and we control for country-specific unobservable characteristics through the inclusion of country fixed effects $\mu_{i}$.

\section{Temporary shocks: demand for agricultural commodi- ties}

\subsection{Micro-level}

Baseline results. We first consider external commodity shocks. As mentioned earlier, we use an indicator of income shock based on the agricultural specialization of the region to which the location belongs, i.e. the foreign demand for the region agricultural products as defined by equation (1). We consider the impact of changes in foreign demand on the probability and intensity of conflict within a given location. We further interact this variable with the

\footnotetext{
${ }^{27}$ As before, this variable is coded as "missing" for ongoing conflicts.
} 
remoteness of the location (the relative distance to the nearest seaport): changes in foreign demand are expected to affect less the most remote locations, for which trade costs are higher - and therefore trade openness is naturally lower.

Table 1: Agricultural commodities shocks and conflicts: baseline results

\begin{tabular}{|c|c|c|c|c|c|c|c|c|c|}
\hline Dep. Var. & \multicolumn{3}{|c|}{ Conflict incidence } & \multicolumn{3}{|c|}{ Conflict onset } & \multicolumn{3}{|c|}{ \# Conflicts } \\
\hline $\begin{array}{l}\text { Estimator } \\
\text { Country spec. trend } \\
\text { Spec. }\end{array}$ & $\begin{array}{c}\text { FE logit } \\
\text { No } \\
(1)\end{array}$ & $\begin{array}{c}\text { FE logit } \\
\text { Yes } \\
(2)\end{array}$ & $\begin{array}{c}\text { FE-LPM } \\
\text { Yes } \\
(3)\end{array}$ & $\begin{array}{c}\text { FE logit } \\
\text { No } \\
(4)\end{array}$ & $\begin{array}{l}\text { FE logit } \\
\text { Yes } \\
(5)\end{array}$ & $\begin{array}{l}\text { FE-LPM } \\
\text { Yes } \\
(6)\end{array}$ & $\begin{array}{l}\text { PPML } \\
\text { No } \\
(7)\end{array}$ & $\begin{array}{l}\text { PPML } \\
\text { Yes } \\
(8)\end{array}$ & $\begin{array}{c}\text { FE-LPM } \\
\text { Yes } \\
(9)\end{array}$ \\
\hline \multicolumn{10}{|l|}{ PANEL A: } \\
\hline ln agr. shock & $\begin{array}{r}-1.312^{a} \\
(0.365)\end{array}$ & $\begin{array}{r}-1.306^{a} \\
(0.434)\end{array}$ & $\begin{array}{l}-0.090^{a} \\
(0.022)\end{array}$ & $\begin{array}{r}-1.317^{a} \\
(0.360)\end{array}$ & $\begin{array}{r}-1.427^{a} \\
(0.401)\end{array}$ & $\begin{array}{r}-0.075^{a} \\
(0.017)\end{array}$ & $\begin{array}{l}-1.071^{b} \\
(0.496)\end{array}$ & $\begin{array}{l}-1.057^{a} \\
(0.407)\end{array}$ & $\begin{array}{l}-0.188^{b} \\
(0.081)\end{array}$ \\
\hline \multicolumn{10}{|l|}{$\underline{\text { PANEL B }}$} \\
\hline ln agr. shock & $\begin{array}{r}-4.135^{a} \\
(0.538)\end{array}$ & $\begin{array}{l}-3.094^{a} \\
(0.587)\end{array}$ & $\begin{array}{l}-0.211^{a} \\
(0.040)\end{array}$ & $\begin{array}{l}-3.635^{a} \\
(0.481)\end{array}$ & $\begin{array}{l}-2.889^{a} \\
(0.534)\end{array}$ & $\begin{array}{l}-0.164^{a} \\
(0.032)\end{array}$ & $\begin{array}{l}-4.240^{a} \\
(0.800)\end{array}$ & $\begin{array}{l}-3.445^{a} \\
(0.570)\end{array}$ & $\begin{array}{l}-0.533^{a} \\
(0.130)\end{array}$ \\
\hline ln agr. shock $\times$ remoteness ${ }^{1}$ & $\begin{array}{l}4.131^{a} \\
(0.498)\end{array}$ & $\begin{array}{l}2.843^{a} \\
(0.583)\end{array}$ & $\begin{array}{r}0.167^{a} \\
(0.043)\end{array}$ & $\begin{array}{c}3.323^{a} \\
(0.408)\end{array}$ & $\begin{array}{l}2.327^{a} \\
(0.518)\end{array}$ & $\begin{array}{l}0.123^{a} \\
(0.034)\end{array}$ & $\begin{array}{l}4.624^{a} \\
(0.540)\end{array}$ & $\begin{array}{l}3.543^{a} \\
(0.610)\end{array}$ & $\begin{array}{l}0.475^{a} \\
(0.147)\end{array}$ \\
\hline
\end{tabular}

Robust standard errors, clustered by location in parentheses. All estimations include year dummies and location fixed effects. ${ }^{c}$ significant at $10 \% ;$ significant at $5 \% ;^{a}$ significant at $1 \%{ }^{1}$ distance to closest seaport relative to maximum distance computed by country. The number of observations is 11,815 in conflict incidence and intensity estimations, 11,472 in conflict onset estimations.

Our baseline results are shown in Table 1. Panel A contains estimations in which the effect is assumed to be the same across regions. Panel B includes the additional interaction term between our shock variable and relative distance to the closest seaport. An increase in world demand of the region's agricultural commodities significantly decreases the probability of conflict incidence (columns (1) to (3)), onset (columns (4) to (6)) and intensity (columns (7) to (9)) within locations in all estimations. The effect is also quantitatively relevant: a 10\% increase in foreign demand decreases the probability of conflict by almost 1 percentage point (column (3)).

The effect is however heterogeneous across locations. In Panel B, we find the coefficient on our interaction between remoteness and our shock variable is always positive and significant, i.e. the probability or intensity of conflict in the least opened locations is significantly less affected by changes in the world demand for the commodity produced by the region. The quantitative interpretation of our results is straightforward: in column (3) we see that for the least most remote locations, a 10 percent increase in foreign demand leads to a 2 percentage points decrease in the conflict probability. On the contrary, the effect is almost zero for the 
most remote locations. ${ }^{28}$

Robustness. Table 2 contains a number of robustness checks. In Panel A and B we first replicate the results of the Table 1 using two alternative indicator of trade openness: the log of distance to the nearest seaport and the roughness of the area. These are a more imperfect proxies: the first can capture the country-specific geographical location, while the second only captures the topology of the region, and not the overall remoteness of the location. Our results are however very similar: in the less opened regions, conflict incidence, onset and intensity are found to be less affected by external changes in demand for the commodities produced by the region.

In panel $\mathrm{C}$, we include a number of additional interactions terms in our estimations. Indeed, our remoteness measure might be correlated with a number of location-specific characteristics affecting the way in which the location responds to external shocks. In particular, remoteness may be correlated with the location's economic size. In the same way, the regions located far from the seaports tend to be also located far from the country's economic and political center (capital city). The correlation between the relative distance to the main seaport and relative distance the capital city is indeed positive and statistically significant, around 0.40. It could therefore be the case that we are identifying the effect of economic activity or political influence, not specifically the effect of trade openness.

We therefore include in our estimations additional interaction terms between our shock variable and (i) distance to the capital city (relative to the maximum distance computed by country); (ii) the log of GDP of the area in 2000; (iii) a dummy representing proximity to an international border, which equals 1 if the location is within a $1 \times 1$ degree cell belonging to two different countries; (iv) a dummy representing the proximity to natural resources (oil and diamond) fields. Natural resources variables are supposed to capture the level of political instability of the region. Two results are worth mentioning. First, the effect of our shock variable, as well as its interaction with the relative distance to seaports, is very robust to the inclusion of these variables. The interaction terms between the shock variables and the relative distance to seaports remain significant at the $1 \%$ levels in all specifications, and the estimated coefficients are quantitatively close to our benchmark estimations. Second and importantly, the

\footnotetext{
${ }^{28}$ Tables 10 and 11 in the appendix replicates our estimations from 1 using another commodity shock variables from Bazzi and Blattman (2011) (Table 10) or our alternative sample (Table 11). In the latter we concentrate on the period 1997-2007, as we do not have disaggregated trade data for the more recent years. We are currently expanding the dataset to include the most recent years.
} 
Table 2: Agricultural commodities shocks and conflicts: robustness

\begin{tabular}{|c|c|c|c|c|c|c|c|c|c|}
\hline Dep. Var. & \multicolumn{3}{|c|}{ Conflict incidence } & \multicolumn{3}{|c|}{ Conflict onset } & \multicolumn{3}{|c|}{ \# Conflicts } \\
\hline $\begin{array}{l}\text { Estimator } \\
\text { Country spec. trend } \\
\text { Spec. }\end{array}$ & $\begin{array}{c}\text { FE logit } \\
\text { No } \\
(1)\end{array}$ & $\begin{array}{c}\text { FE logit } \\
\text { Yes } \\
(2)\end{array}$ & $\begin{array}{c}\text { FE-LPM } \\
\text { Yes } \\
(3)\end{array}$ & $\begin{array}{c}\text { FE logit } \\
\text { No } \\
(4)\end{array}$ & $\begin{array}{l}\text { FE logit } \\
\text { Yes } \\
(5)\end{array}$ & $\begin{array}{c}\text { FE-LPM } \\
\text { Yes } \\
(6)\end{array}$ & $\begin{array}{l}\text { PPML } \\
\text { No } \\
(7)\end{array}$ & $\begin{array}{l}\text { PPML } \\
\text { Yes } \\
(8)\end{array}$ & $\begin{array}{c}\text { FE-LPM } \\
\text { Yes } \\
(9)\end{array}$ \\
\hline \multicolumn{10}{|l|}{$\underline{\text { PANEL A }}$} \\
\hline ln agr. shock & $\begin{array}{c}-7.539^{a} \\
(1.114)\end{array}$ & $\begin{array}{c}-4.732^{a} \\
(0.994)\end{array}$ & $\begin{array}{c}-0.339^{a} \\
(0.083)\end{array}$ & $\begin{array}{c}-6.692^{a} \\
(0.912)\end{array}$ & $\begin{array}{c}-4.584^{a} \\
(0.904)\end{array}$ & $\begin{array}{c}-0.276^{a} \\
(0.063)\end{array}$ & $\begin{array}{c}-6.338^{a} \\
(0.873)\end{array}$ & $\begin{array}{c}-4.299^{a} \\
(0.783)\end{array}$ & $\begin{array}{c}-0.867^{b} \\
(0.364)\end{array}$ \\
\hline ln agr. shock $\times$ remoteness $(2)$ & $\begin{array}{l}1.008^{a} \\
(0.160)\end{array}$ & $\begin{array}{l}0.581^{a} \\
(0.143)\end{array}$ & $\begin{array}{c}0.039^{a} \\
(0.012)\end{array}$ & $\begin{array}{c}0.863^{a} \\
(0.128)\end{array}$ & $\begin{array}{c}0.537^{a} \\
(0.129)\end{array}$ & $\begin{array}{c}0.031^{a} \\
(0.009)\end{array}$ & $\begin{array}{c}0.837^{a} \\
(0.089)\end{array}$ & $\begin{array}{c}0.523^{a} \\
(0.103)\end{array}$ & $\begin{array}{c}0.106^{c} \\
(0.055)\end{array}$ \\
\hline \multicolumn{10}{|l|}{ PANEL B } \\
\hline ln agr. shock & $\begin{array}{c}-1.999^{a} \\
(0.459)\end{array}$ & $\begin{array}{c}-1.761^{a} \\
(0.454)\end{array}$ & $\begin{array}{c}-0.133^{a} \\
(0.025)\end{array}$ & $\begin{array}{c}-1.747^{a} \\
(0.439)\end{array}$ & $\begin{array}{c}-1.710^{a} \\
(0.421)\end{array}$ & $\begin{array}{c}-0.101^{a} \\
(0.020)\end{array}$ & $\begin{array}{c}-1.903^{a} \\
(0.686)\end{array}$ & $\begin{array}{c}-1.840^{a} \\
(0.391)\end{array}$ & $\begin{array}{c}-0.321^{a} \\
(0.086)\end{array}$ \\
\hline ln agr. shock $\times$ remoteness $(3)$ & $\begin{array}{l}2.794^{a} \\
(0.912)\end{array}$ & $\begin{array}{c}2.328^{b} \\
(1.177)\end{array}$ & $\begin{array}{c}0.148^{a} \\
(0.048)\end{array}$ & $\begin{array}{l}1.641^{b} \\
(0.791)\end{array}$ & $\begin{array}{c}1.391 \\
(0.980)\end{array}$ & $\begin{array}{c}0.090^{a} \\
(0.034)\end{array}$ & $\begin{array}{c}3.398^{a} \\
(1.064)\end{array}$ & $\begin{array}{c}4.057^{a} \\
(1.267)\end{array}$ & $\begin{array}{c}0.460^{a} \\
(0.126)\end{array}$ \\
\hline \multicolumn{10}{|l|}{$\underline{\text { PANEL C }}$} \\
\hline ln agr. shock & $\begin{array}{c}-3.690^{a} \\
(0.643)\end{array}$ & $\begin{array}{c}-3.114^{a} \\
(0.652)\end{array}$ & $\begin{array}{c}-0.215^{a} \\
(0.042)\end{array}$ & $\begin{array}{c}-3.208^{a} \\
(0.589)\end{array}$ & $\begin{array}{c}-2.729^{a} \\
(0.596)\end{array}$ & $\begin{array}{c}-0.155^{a} \\
(0.033)\end{array}$ & $\begin{array}{c}-3.831^{a} \\
(0.942)\end{array}$ & $\begin{array}{c}-3.386^{a} \\
(0.593)\end{array}$ & $\begin{array}{r}-0.532^{a} \\
(0.137)\end{array}$ \\
\hline ln agr. shock $\times$ remoteness $(1)$ & $\begin{array}{l}2.333^{a} \\
(0.711)\end{array}$ & $\begin{array}{c}1.729^{b} \\
(0.735)\end{array}$ & $\begin{array}{l}0.127^{a} \\
(0.048)\end{array}$ & $\begin{array}{l}1.953^{a} \\
(0.627)\end{array}$ & $\begin{array}{c}1.447^{b} \\
(0.674)\end{array}$ & $\begin{array}{c}0.095^{b} \\
(0.037)\end{array}$ & $\begin{array}{l}2.319^{a} \\
(0.763)\end{array}$ & $\begin{array}{c}2.190^{a} \\
(0.756)\end{array}$ & $\begin{array}{c}0.386^{b} \\
(0.154)\end{array}$ \\
\hline ln agr. shock $\times \ln$ dist. to cap. & $\begin{array}{l}1.867^{a} \\
(0.608)\end{array}$ & $\begin{array}{c}0.801 \\
(0.613)\end{array}$ & $\begin{array}{c}0.000 \\
(0.031)\end{array}$ & $\begin{array}{l}1.774^{a} \\
(0.558)\end{array}$ & $\begin{array}{c}0.864 \\
(0.586)\end{array}$ & $\begin{array}{c}0.004 \\
(0.023)\end{array}$ & $\begin{array}{l}1.896^{a} \\
(0.563)\end{array}$ & $\begin{array}{c}0.072 \\
(0.624)\end{array}$ & $\begin{array}{l}-0.075 \\
(0.133)\end{array}$ \\
\hline ln agr. shock $\times$ ln GDP area & $\begin{array}{c}-0.012 \\
(0.009)\end{array}$ & $\begin{array}{c}-0.013 \\
(0.009)\end{array}$ & $\begin{array}{c}-0.001 \\
(0.001)\end{array}$ & $\begin{array}{c}-0.011 \\
(0.009)\end{array}$ & $\begin{array}{c}-0.014 \\
(0.009)\end{array}$ & $\begin{array}{c}-0.001 \\
(0.001)\end{array}$ & $\begin{array}{c}-0.015^{c} \\
(0.008)\end{array}$ & $\begin{array}{l}-0.017^{b} \\
(0.009)\end{array}$ & $\begin{array}{l}-0.003 \\
(0.002)\end{array}$ \\
\hline ln agr. shock $\times$ border & $\begin{array}{c}0.389 \\
(0.400)\end{array}$ & $\begin{array}{c}0.842^{c} \\
(0.430)\end{array}$ & $\begin{array}{l}0.050^{a} \\
(0.018)\end{array}$ & $\begin{array}{c}0.006 \\
(0.375)\end{array}$ & $\begin{array}{c}0.367 \\
(0.401)\end{array}$ & $\begin{array}{c}0.021 \\
(0.014)\end{array}$ & $\begin{array}{c}0.884^{c} \\
(0.457)\end{array}$ & $\begin{array}{l}1.400^{a} \\
(0.500)\end{array}$ & $\begin{array}{l}0.159^{a} \\
(0.052)\end{array}$ \\
\hline Exp. to crises $\times$ nat. ress. & $\begin{array}{c}-1.848^{a} \\
(0.462)\end{array}$ & $\begin{array}{c}-0.843 \\
(0.520)\end{array}$ & $\begin{array}{c}-0.037 \\
(0.041)\end{array}$ & $\begin{array}{c}-1.683^{a} \\
(0.402)\end{array}$ & $\begin{array}{c}-1.065^{b} \\
(0.475)\end{array}$ & $\begin{array}{c}-0.059^{c} \\
(0.032)\end{array}$ & $\begin{array}{c}-1.626^{a} \\
(0.485)\end{array}$ & $\begin{array}{c}-0.770 \\
(0.505)\end{array}$ & $\begin{array}{c}-0.101 \\
(0.089)\end{array}$ \\
\hline
\end{tabular}

Robust standard errors, clustered by location in parentheses. All estimations include year dummies and location fixed effects. ${ }^{c}$ significant at $10 \%$; ${ }^{b}$ significant at 5\%; a significant at $1 \%$. (1) distance to closest seaport relative to maximum distance computed by country. (2) ln distance to closest significant at $5 \%$; a significant at $1 \%$. (1) distance seaport. (3) roughness of terrain from G-econ; rel. dist. to cap.: distance to capital city relative to maximum distance computed by country; lin GDP area: GDP of the area in 2000, from G-econ; nat. ress.: dummy which equals 1 if the location is within $100 \mathrm{~km}$ of an oil or or dianond field. The number of observations is 11,815 in conflict incidence and intensity estimations, 11,472 in conflict onset estimations.

coefficients of the interaction terms with distance to the capital city and the GDP of the area are much less robust. This clearly suggests that we are capturing an income effect of external shocks on conflict that channels through international trade, rather than an effect related to the economic size or the political instability of the location. 


\subsection{Country-level results}

The results presented in the previous section suggest that external income shocks affect the probability of conflict within locations, and therefore conflict intensity at the country-level. However, they do not allow us to determine whether they are significant determinants of conflict outbreak at the country-level. In this subsection, we consider the effect of external commodities shocks on conflict at country-level (equation (9)). The dependent variable is a dummy which equals 1 if at least one location in the country experienced a violent event during the year. Note that results are very similar when we use country-specific UCDP/PRIO data on conflict incidence or onset. Our estimations include year dummies and country-specific trends. More importantly, we include country fixed effects, and therefore identify the effects of income shocks on the start or ending of civil conflicts.

Table 3: Agricultural commodities shocks and conflicts: country-level results

\begin{tabular}{|c|c|c|c|c|c|c|c|}
\hline \multirow{2}{*}{$\begin{array}{l}\text { Aggregation } \\
\text { Dep. var. } \\
\text { Estimator } \\
\text { Spec. }\end{array}$} & $\begin{array}{c}\text { Incidence } \\
\text { FE-LI }\end{array}$ & $\begin{array}{l}\text { Cou } \\
\text { Onset } \\
\mathrm{PM}\end{array}$ & $\begin{array}{l}\text { try level } \\
\text { Intensity* } \\
\text { PI }\end{array}$ & $\begin{array}{l}\text { Intensity** } \\
\text { ML }\end{array}$ & \multicolumn{3}{|c|}{$\begin{array}{c}\text { Location level } \\
\text { Onset (if Conflict } \text { it, }_{i, 1}=0 \\
\text { FE-LPM }\end{array}$} \\
\hline & $(1)$ & (2) & $(3)$ & (4) & $(5)$ & $(6)$ & $(7)$ \\
\hline ln shock & $\begin{array}{l}-0.557 \\
(0.537)\end{array}$ & $\begin{array}{c}8.269 \\
(5.910)\end{array}$ & $\begin{array}{l}-5.754^{a} \\
(2.075)\end{array}$ & $\begin{array}{l}-5.405^{b} \\
(2.660)\end{array}$ & $\begin{array}{l}-0.015 \\
(0.012)\end{array}$ & $\begin{array}{l}-0.006 \\
(0.028)\end{array}$ & $\begin{array}{l}-0.008 \\
(0.018)\end{array}$ \\
\hline ln agr. shock $\times \ln$ dist. to closest port $(1)$ & & & & & & $\begin{array}{c}-0.002 \\
(0.004)\end{array}$ & \\
\hline ln shock $\times$ remoteness $(2)$ & & & & & & & $\begin{array}{l}-0.015 \\
(0.031)\end{array}$ \\
\hline Observations & 119 & 37 & 119 & 119 & 3234 & 3234 & 3234 \\
\hline
\end{tabular}

Robust standard errors, clustered by location in parentheses. ${ }^{1}$ ln distance to closest seaport; ${ }^{2}$ distance to closest seaport relative to maximum distance computed by country; ${ }^{*}$ number of locations with violent events during year $t ;{ }^{*} *$ total number of violent events during year $t$. Estimations (1) to (4) include country fixed effects, estimations (5) and (6) include location fixed effects. All estimations include year dummies and country-specific trends. ${ }^{c}$ significant at $10 \%{ }^{b}$ significant at $5 \%{ }^{a}$ significant at $1 \%$. (1) distance to closest seaport relative to maximum distance computed by country. (2) ln distance to closest seaport

Consistent with Bazzi and Blattman (2011), we cannot detect any significant effect of our commodity demand shock, except on conflict intensity, which is consistent with our micro-level results (Table 3 columns 1-4). Note that to detect an effect of commodity price shocks on conflict incidence at the country level, we need commodity prices shocks to affect conflict onset or ending, as with country fixed effects, the identification of an effect is only possible when the dependent variable switches from zero to one or inversely. Our interpretation of these results 
is the following.

First, according to our findings above, remote locations are naturally less affected by external commodities shocks. At the same time, conflicts tend to start in relatively remote locations. Figure 1 shows the cumulative distribution of the relative distance of each location to the closest port. We report three cumulative distributions: for the locations in which no conflict conflict happens during the period (labeled "Peace"); for the locations where the conflict started at the same time that the conflict in the country (labeled "Onset"); and for the locations in which conflicts appeared after the outbreak of the event at the country-level (labeled "No onset"). It confirms that conflicts tend to start in relatively remote locations which are less affected by external commodities shock.

Figure 1: Cumulative distribution of relative distance

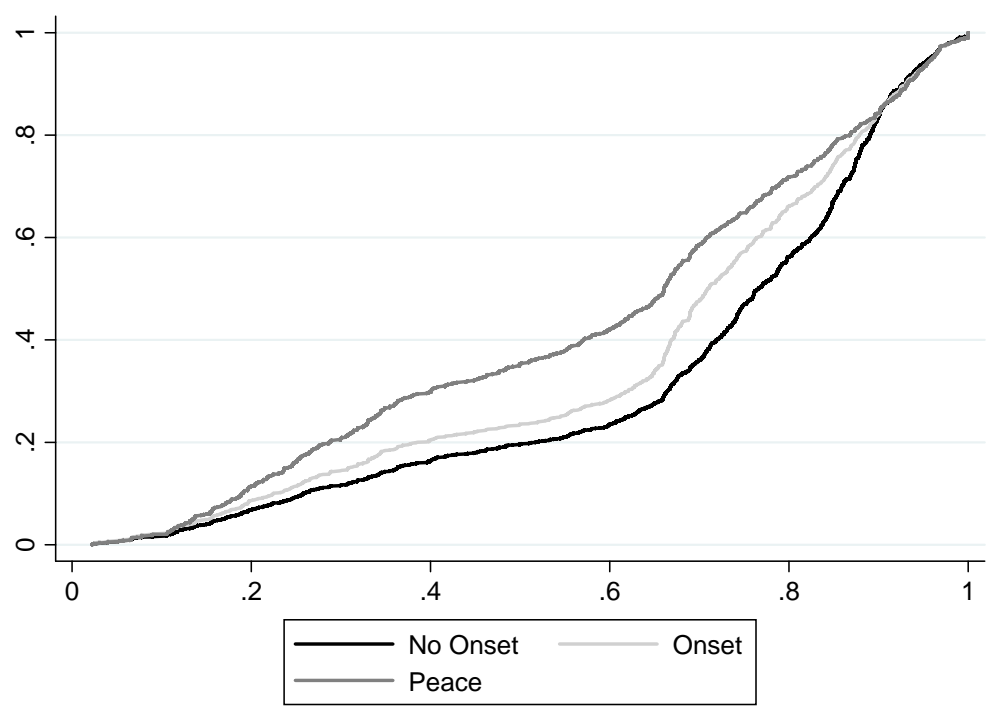

"peace": cumulative distributions of relative distance for locations in which no conflict conflict happens during the period. "onset": cumulative distributions of relative distance for locations where the conflict started at the same time that the conflict in the country (labeled ); "No onset": cumulative distributions of relative distance for locations in which conflicts appeared after the outbreak of the event at the country-level.

Therefore, income shocks in general might not be a significant determinant of conflict outbreak, but rather a factor affecting the geographical evolution and the intensity of conflicts within countries. This is all the more likely for commodity prices or commodity demand variations, which are generally limited, and - more importantly - temporary, or considered as such. Indeed, we do not find any significant effect of our commodity shock variable on conflict onset at the location level, that is, on the probability of a conflict outbreak in a given location, conditional on no other location being in civil conflict the year before (Table 3, columns 5-7). The effect of these shocks is therefore due to the change in the conflict probability within location 
once the conflict has started.

Are these results relevant for any type of (foreign) income shocks? In the next section, we show that considering larger and longer-lasting shocks leads to slightly different conclusions.

\section{Long-lasting shocks: financial crises and trade policy}

\subsection{Micro Results}

Long-lasting Shock \# I: Exposure to financial crises. The first type of long-lasting income shocks we consider is the exposure of the country to financial crises in its trading partners. This variable has a negative impact on the country's income through lower exports. On the other hand, this impact on income should be lower on regions located further away from the main sea ports. Table 4 contains the results of our estimations. Panel A contains the results of estimations where only the crisis exposure variable is included. In Panel B, we add the interaction term between exposure and the distance from the location to the closest sea port. Again, we consider both conflict probability (estimations (1) to (3) of each panel), onset (estimations (4) and (5)) or intensity (estimations (6) to (8)).

Table 4: Exposure to crises and conflicts: baseline results

\begin{tabular}{|c|c|c|c|c|c|c|c|c|}
\hline Dep. Var. & \multicolumn{3}{|c|}{ Conflict incidence } & \multicolumn{2}{|c|}{ Conflict onset } & \multicolumn{3}{|c|}{ \# Conflicts } \\
\hline $\begin{array}{l}\text { Estimator } \\
\text { Country spec. trend } \\
\text { Spec. }\end{array}$ & $\begin{array}{c}\text { FE logit } \\
\text { No } \\
(1)\end{array}$ & $\begin{array}{l}\text { FE logit } \\
\text { Yes } \\
(2)\end{array}$ & $\begin{array}{c}\text { FE-LPM } \\
\text { Yes } \\
(3)\end{array}$ & $\begin{array}{c}\text { FE logit } \\
\text { No } \\
(4)\end{array}$ & $\begin{array}{c}\text { FE-LPM } \\
\text { Yes } \\
(5)\end{array}$ & $\begin{array}{l}\text { PPML } \\
\text { No } \\
(6)\end{array}$ & $\begin{array}{l}\text { PPML } \\
\text { Yes } \\
(7)\end{array}$ & $\begin{array}{c}\text { FE-LPM } \\
\text { Yes } \\
(8)\end{array}$ \\
\hline \multicolumn{9}{|l|}{ PANEL A } \\
\hline Exposure to crises & $\begin{array}{c}0.047 \\
(0.537)\end{array}$ & $\begin{array}{l}-0.166 \\
(0.544)\end{array}$ & $\begin{array}{l}-0.031 \\
(0.041)\end{array}$ & $\begin{array}{c}0.477 \\
(0.578)\end{array}$ & $\begin{array}{c}0.010 \\
(0.037)\end{array}$ & $\begin{array}{c}0.429 \\
(0.635)\end{array}$ & $\begin{array}{c}0.385 \\
(0.649)\end{array}$ & $\begin{array}{l}-0.037 \\
(0.104)\end{array}$ \\
\hline \multicolumn{9}{|l|}{ PANEL B } \\
\hline Exposure to crises & $\begin{array}{c}4.040^{a} \\
(0.706)\end{array}$ & $\begin{array}{c}4.980^{a} \\
(0.715)\end{array}$ & $\begin{array}{c}0.312^{a} \\
(0.059)\end{array}$ & $\begin{array}{c}4.196^{a} \\
(0.762)\end{array}$ & $\begin{array}{c}0.258^{a} \\
(0.051)\end{array}$ & $\begin{array}{c}3.621^{a} \\
(0.979)\end{array}$ & $\begin{array}{c}4.249^{a} \\
(0.993)\end{array}$ & $\begin{array}{c}0.591^{a} \\
(0.190)\end{array}$ \\
\hline Exp. to crises $\times$ remoteness $^{1}$ & $\begin{array}{r}-7.495^{a} \\
(1.043)\end{array}$ & $\begin{array}{l}-9.663^{a} \\
(1.092)\end{array}$ & $\begin{array}{c}-0.626^{a} \\
(0.082)\end{array}$ & $\begin{array}{l}-6.865^{a} \\
(1.098)\end{array}$ & $\begin{array}{l}-0.451^{a} \\
(0.068)\end{array}$ & $\begin{array}{l}-6.322^{a} \\
(1.395)\end{array}$ & $\begin{array}{l}-7.740^{a} \\
(1.484)\end{array}$ & $\begin{array}{l}-1.143^{a} \\
(0.232)\end{array}$ \\
\hline
\end{tabular}

Robust standard errors, clustered by location in parentheses. All estimations include year dummies and location fixed effects. ${ }^{c}$ significant at $10 \%$; ${ }^{b}$ Robust standard errors, clustered by location in parentheses. All estimations include year dummies and location fixed effects. ${ }^{c}$ significant at $10 \%$;
significant at $5 \%{ }^{a}$ significant at $1 \%$. (1) distance to closest seaport relative to maximum distance computed by country. The number of observations significant at $5 \%$; ${ }^{a}$ significant at $1 \%$. (1) distance to closest seaport relative to maximum dista
is 27,378 in conflict incidence and intensity estimations, 26,817 in conflict onset estimations.

On average across locations, the effect of exposure to financial crises in partner countries is 
statistically insignificant (Table 4, Panel A). This is however due to the fact that the impact is heterogeneous across regions. Introducing the interaction term between exposure to crises and remoteness confirms this heterogeneity (Panel B). For the least remote locations, the effect of financial crises in partner countries is positive and significant. The interaction term is negative and significant, i.e. distance to seaports dampens the effect of negative income shocks on conflict probability, onset and intensity. This is the case both when using non linear (FE Logit and Poisson) or linear (OLS) estimators, as well as when including country-specific time trends. The effect is also quantitatively relevant: for the seaport itself (relative distance equal to 0), a standard deviation increase in the exposure to crises variable raises conflict probability by almost 4 percentage points (based on column (3)). Note that we find in Table 4 that for the most remote locations, the effect of exposure of foreign financial crises on conflict probability is actually negative and significant (summing the coefficients of Panel B, columns (3), (5) or (8)). This result is however not robust to the inclusion of additional interaction terms between the shocks and location-specific characteristics (see Table 12, Panel $\mathrm{C}$ in the appendix), or to the use of our alternative sample (Table 13). On the other hand, these robustness exercises show that our baseline results (exposure to crises has a positive effect on conflict probability, the more so in the most opened locations) are remarkably robustto the inclusion of additional interactions and to the use of our alternative sample.

Long-lasting Shock \# II: African Growth Opportunity Act. The last shock we consider is the entry of the country into the African Growth Act Opportunity. Starting in 2000, the US granted free access to a number of products to most Sub-Saharan African countries. As explained before, the scope and timing of this gain in market access differed according to the country. As shown by Frazer and Biesebroeck (2010), the AGOA had a positive and significant effect on these countries' total exports. We study the impact of this positive income shock on conflict probability, onset and intensity within African countries.

The results are provided in Table 5. Beyond the AGOA dummy, we include a number of interaction terms to check that we are indeed identifying the effect of this trade policy changes. In estimations (1) to (8) of panel A, we interact the AGOA dummy with the country's pre-AGOA share of total exports in the product eligible to the AGOA. Entering the AGOA significantly decreases both the probability of conflict and the intensity. As expected, the effect is more pronounced for the countries specialized in the products eligible to the AGOA. Second, 
we interact the AGOA dummy with the distance between the country's main seaport and the US (New York City) in estimations (1) to (8) of panel B of Table 5. Distance to the US limits the effect of the AGOA on exports, and in turn income and conflict likelihood: the interaction term is positive and significant in all estimations.

Table 5: AGOA and conflicts: baseline results

\begin{tabular}{|c|c|c|c|c|c|c|c|c|}
\hline Dep. Var. & \multicolumn{3}{|c|}{ Conflict incidence } & \multicolumn{2}{|c|}{ Conflict onset } & \multicolumn{3}{|c|}{ \# Conflicts } \\
\hline $\begin{array}{l}\text { Estimator } \\
\text { Country spec. trend } \\
\text { Spec. }\end{array}$ & $\begin{array}{l}\text { FE logit } \\
\text { No } \\
(1)\end{array}$ & $\begin{array}{c}\text { FE logit } \\
\text { Yes } \\
(2)\end{array}$ & $\begin{array}{c}\text { FE-LPM } \\
\text { Yes } \\
(3)\end{array}$ & $\begin{array}{l}\text { FE logit } \\
\text { No } \\
(4)\end{array}$ & $\begin{array}{c}\text { FE-LPM } \\
\text { Yes } \\
(5)\end{array}$ & $\begin{array}{l}\text { FE Poisson } \\
\text { No } \\
(6)\end{array}$ & $\begin{array}{l}\text { FE Poisson } \\
\text { Yes } \\
(7)\end{array}$ & $\begin{array}{c}\text { FE-LPM } \\
\text { Yes } \\
(8)\end{array}$ \\
\hline \multicolumn{9}{|l|}{ PANEL A } \\
\hline AGOA dummy & $\begin{array}{c}-0.730^{a} \\
(0.130)\end{array}$ & $\begin{array}{c}-1.172^{a} \\
(0.186)\end{array}$ & $\begin{array}{c}-0.033^{a} \\
(0.011)\end{array}$ & $\begin{array}{l}-0.647^{a} \\
(0.123)\end{array}$ & $\begin{array}{l}-0.025^{a} \\
(0.009)\end{array}$ & $\begin{array}{l}-1.052^{a} \\
(0.200)\end{array}$ & $\begin{array}{l}-1.553^{a} \\
(0.260)\end{array}$ & $\begin{array}{c}-0.159^{a} \\
(0.056)\end{array}$ \\
\hline AGOA $\times$ Exposure & $\begin{array}{c}-5.806^{a} \\
(1.327)\end{array}$ & $\begin{array}{c}-22.743^{a} \\
(2.795)\end{array}$ & $\begin{array}{c}-0.154^{a} \\
(0.048)\end{array}$ & $\begin{array}{c}-5.278^{a} \\
(1.180)\end{array}$ & $\begin{array}{c}-0.130^{a} \\
(0.037)\end{array}$ & $\begin{array}{l}-8.733^{a} \\
(1.995)\end{array}$ & $\begin{array}{c}-23.436^{a} \\
(3.491)\end{array}$ & $\begin{array}{c}-0.362^{b} \\
(0.159)\end{array}$ \\
\hline \multicolumn{9}{|l|}{ PANEL B } \\
\hline AGOA dummy & $\begin{array}{c}-1.235^{a} \\
(0.166)\end{array}$ & $\begin{array}{c}-1.660^{a} \\
(0.239)\end{array}$ & $\begin{array}{c}-0.036^{a} \\
(0.011)\end{array}$ & $\begin{array}{l}-1.144^{a} \\
(0.158)\end{array}$ & $\begin{array}{l}-0.028^{a} \\
(0.009)\end{array}$ & $\begin{array}{l}-1.584^{a} \\
(0.228)\end{array}$ & $\begin{array}{l}-1.995^{a} \\
(0.234)\end{array}$ & $\begin{array}{l}-0.167^{a} \\
(0.056)\end{array}$ \\
\hline AGOA $\times \ln$ dist. to $\mathrm{US}$ & $\begin{array}{l}7.495^{a} \\
(0.930)\end{array}$ & $\begin{array}{l}13.484^{a} \\
(1.431)\end{array}$ & $\begin{array}{c}0.402^{a} \\
(0.033)\end{array}$ & $\begin{array}{c}7.264^{a} \\
(0.851)\end{array}$ & $\begin{array}{c}0.311^{a} \\
(0.021)\end{array}$ & $\begin{array}{l}8.671^{a} \\
(1.347)\end{array}$ & $\begin{array}{l}12.747^{a} \\
(1.658)\end{array}$ & $\begin{array}{l}0.871^{a} \\
(0.181)\end{array}$ \\
\hline \multicolumn{9}{|l|}{ PANEL C } \\
\hline AGOA dummy & $\begin{array}{c}-3.290^{a} \\
(0.504)\end{array}$ & $\begin{array}{c}-5.206^{a} \\
(0.673)\end{array}$ & $\begin{array}{c}-0.180^{a} \\
(0.018)\end{array}$ & $\begin{array}{l}-2.848^{a} \\
(0.438)\end{array}$ & $\begin{array}{c}-0.131^{a} \\
(0.013)\end{array}$ & $\begin{array}{l}-4.419^{a} \\
(0.675)\end{array}$ & $\begin{array}{c}-6.552^{a} \\
(0.922)\end{array}$ & $\begin{array}{c}-0.504^{a} \\
(0.079)\end{array}$ \\
\hline $\mathrm{AGOA} \times$ remoteness $^{1}$ & $\begin{array}{l}3.814^{a} \\
(0.638)\end{array}$ & $\begin{array}{c}6.686^{a} \\
(0.859)\end{array}$ & $\begin{array}{c}0.227^{a} \\
(0.024)\end{array}$ & $\begin{array}{c}3.302^{a} \\
(0.549)\end{array}$ & $\begin{array}{c}0.164^{a} \\
(0.017)\end{array}$ & $\begin{array}{c}5.027^{a} \\
(0.833)\end{array}$ & $\begin{array}{c}7.947^{a} \\
(1.114)\end{array}$ & $\begin{array}{c}0.533^{a} \\
(0.095)\end{array}$ \\
\hline
\end{tabular}

Robust standard errors, clustered by location in parentheses. All estimations include year dummies and location fixed effects. ${ }^{c}$ significant at $10 \% ;{ }^{b}$ significant at $5 \%$; ${ }^{a}$ significant at $1 \%$. (1) distance to closest seaport relative to maximum distance computed by country. The number of observations is 27,378 in conflict incidence and intensity estimations, 26,817 in conflict onset estimations.

Finally, consistent with our previous estimates, the effect is heterogeneous within country. In panel $\mathrm{C}$, we find that the most remote regions relative to the main seaports are roughly unaffected by the AGOA, while conflict probability decreases by 18 percentage points for the seaport itself. This is consistent with our previous results on financial crises and agricultural commodities. Again, these results are robust to the use of alternative remoteness indicators, to the inclusion of additional interactions, and to the use of our alternative sample (see Tables 14 and 15 in the appendix).

Robustness. The results presented so far are also robust to a number of other additional 
robustness checks. These include: (i) the use of an alternative measure of distance to the nearest seaport, including only ports located in the same country - therefore excluding landlocked countries; (ii) aggregating the data into $1 \times 1$ degree cells (see Table 16 in the appendix). Complete results for these exercises are available upon request.

\subsection{Country-level results}

As in subsection 5.2, we now consider both the effect of exposure to crisis and AGOA on conflict incidence, onset and intensity at country-level (equation (9)). The results are presented in Table 6. Panel A considers exposure to crises, while Panel B considers the AGOA. Whatever the considered shock, the effect is not significant on conflict incidence and onset (columns 1 and 2 of each Panel). Consistent with our micro-level results, the AGOA has a negative effect on conflict intensity a the country-level (Panel B, columns 3-4). The reasons given to explain the lack of effect of commodities shocks are the same: remote locations are less affected by commodities shocks and income shocks in general might not be a significant determinant of conflict outbreak, but rather a factor affecting the geographical evolution and the intensity of conflicts within countries.

Columns (5) to (7) in Table 6 shed light this last argument. Contrary to commodity shocks, both persistent shocks do affect conflict onset at the location level for the least remote locations, that is, the probability of a conflict outbreak in "opened" locations, conditional on no other location in the country experiencing a conflict the year before. One way to interpret the difference between these various results is the following: conflicts tend to start in remote locations, which make the identification of an effect of external shocks difficult. Moreover, only large and long-lasting shocks may durably affect income, and therefore the opportunity costs of war and conflict onset at the country-level.

\section{Interpretation and discussion}

Our analysis so far yielded two important conclusions. First, external income shocks affect significantly the incidence, onset, and intensity of conflict within locations in the considered set of Sub-Saharan African countries. This is consistent with Dube and Vargas (2011). However, these same shocks have in general no effect on conflict onset or incidence at the country-level. 
Table 6: Long-lasting shocks and and conflicts: country-level results

\begin{tabular}{|c|c|c|c|c|c|c|c|}
\hline \multirow{2}{*}{$\begin{array}{l}\text { Aggregation } \\
\text { Dep. var. } \\
\text { Estimator } \\
\text { Spec. }\end{array}$} & \multirow{2}{*}{$\begin{array}{l}\text { Incidence } \\
\text { FE-LF } \\
(1)\end{array}$} & $\begin{array}{l}\text { Onset } \\
\mathrm{M}\end{array}$ & \multicolumn{2}{|c|}{$\begin{array}{c}\text { Intensity* }^{*} \text { Intensity } \\
\text { PPML }\end{array}$} & \multicolumn{3}{|c|}{$\begin{array}{c}\text { Location level } \\
\text { Onset } \text { (if Conflict }_{i, t-1}=0 \\
\text { FE-LPM }\end{array}$} \\
\hline & & $(2)$ & $(3)$ & (4) & $(5)$ & (6) & $(7)$ \\
\hline PANEL A & & & & & & & \\
\hline shock & $\begin{array}{l}-0.320 \\
(0.349)\end{array}$ & $\begin{array}{c}0.882 \\
(0.929)\end{array}$ & $\begin{array}{l}-0.112 \\
(1.067)\end{array}$ & $\begin{array}{c}0.385 \\
(1.428)\end{array}$ & $\begin{array}{l}0.286^{a} \\
(0.039)\end{array}$ & $\begin{array}{l}0.553^{a} \\
(0.133)\end{array}$ & $\begin{array}{l}0.330^{a} \\
(0.067)\end{array}$ \\
\hline Exp. to crises $\times$ remoteness $(1)$ & & & & & & $\begin{array}{l}-0.065^{b} \\
(0.028)\end{array}$ & \\
\hline Exp. to crises $\times$ remoteness $(2)$ & & & & & & & $\begin{array}{l}-0.111 \\
(0.127)\end{array}$ \\
\hline Observations & 208 & 100 & 208 & 208 & 10390 & 10390 & 10390 \\
\hline PANEL B & & & & & & & \\
\hline AGOA dummy & $\begin{array}{l}-0.167 \\
(0.235)\end{array}$ & $\begin{array}{l}-5.126 \\
(4.923)\end{array}$ & $\begin{array}{l}-1.298^{a} \\
(0.417)\end{array}$ & $\begin{array}{l}-1.866^{a} \\
(0.487)\end{array}$ & $\begin{array}{l}-0.025^{a} \\
(0.006)\end{array}$ & $\begin{array}{l}-0.097^{a} \\
(0.019)\end{array}$ & $\begin{array}{l}-0.026^{a} \\
(0.007)\end{array}$ \\
\hline AGOA $\times$ remoteness $(1)$ & & & & & & $\begin{array}{l}0.014^{a} \\
(0.003)\end{array}$ & \\
\hline AGOA $\times$ remoteness $(2)$ & & & & & & & $\begin{array}{c}0.001 \\
(0.011)\end{array}$ \\
\hline Observations & 119 & 38 & 119 & 119 & 10392 & 10390 & 10390 \\
\hline
\end{tabular}

Robust standard errors, clustered by location in parentheses. ${ }^{1}$ ln distance to closest seaport; ${ }^{*}$ number of locations with violent events during year $t ;{ }^{* *}$ total number of violent events during year $t$. Estimations (1) to (4) include country fixed effects, estimations (5) and (6) include location fixed effects. All estimations include year dummies and country-specific trends. ${ }^{c}$ significant at $10 \%{ }^{b}$ significant at $5 \%$; ${ }^{a}$ significant at $1 \%$. (1) ln distance to closest seaport. (2) distance to closest seaport relative to maximum distance computed by country.

This is consistent with Bazzi and Blattman (2011). We can reconcile these apparently contrary findings by noting that conflicts tend to start in remote locations, which are less likely to be affected by external shocks. When the shocks are large and long-lasting, however, it seems that they influence the probability that a country-wide conflict starts in a specific location, depending on its remoteness. Our findings therefore suggest that external income shocks are important to understand the geography and intensity of conflicts, but that they are probably not the main determinants of the outbreak of a conflict at the country-level.

Our second important finding is that the effect of income shocks survives to the inclusion of various location-specific characteristics, such as distance to the country's political center (its capital city). This is particularly important as our effect of income shocks on conflict probability 
could as well be interpreted as evidence of the state capacity hypothesis, according to which positive income shock provide the state with the (financial) means to prevent conflicts. This state capacity effect should be more prevalent in regions located close to the political center, where the state influence is stronger (Buhaug, 2010). This allows us to interpret our results as evidence in favor of the opportunity cost effect of economic shocks. 
Table 7: External shocks and regional GDP per capita

\begin{tabular}{|c|c|c|c|c|c|c|}
\hline Dep. Var. & \multicolumn{2}{|c|}{ ln GDP per cap. } & \multicolumn{2}{|c|}{ ln GDP per cap. } & \multicolumn{2}{|c|}{ ln GDP per cap. } \\
\hline Shock & \multicolumn{2}{|c|}{ Commodities } & \multicolumn{2}{|c|}{ Crises } & \multicolumn{2}{|c|}{ AGOA } \\
\hline Spec. & $(1)$ & $(2)$ & $(3)$ & $(4)$ & $(5)$ & $(6)$ \\
\hline Shock & $\begin{array}{c}0.331^{a} \\
(0.050)\end{array}$ & $\begin{array}{c}0.287^{a} \\
(0.063)\end{array}$ & $\begin{array}{c}-0.227^{a} \\
(0.039)\end{array}$ & $\begin{array}{l}-0.143^{a} \\
(0.047)\end{array}$ & $\begin{array}{c}0.283^{a} \\
(0.033)\end{array}$ & $\begin{array}{c}0.230^{a} \\
(0.036)\end{array}$ \\
\hline Shock $\times$ remoteness $(1)$ & $\begin{array}{c}-0.465^{a} \\
(0.058)\end{array}$ & $\begin{array}{c}-0.519^{a} \\
(0.063)\end{array}$ & $\begin{array}{c}0.359^{a} \\
(0.048)\end{array}$ & $\begin{array}{c}0.466^{a} \\
(0.064)\end{array}$ & $\begin{array}{c}-0.422^{a} \\
(0.048)\end{array}$ & $\begin{array}{c}-0.567^{a} \\
(0.062)\end{array}$ \\
\hline Shock $\times \ln$ dist. to capital $(2)$ & & $\begin{array}{c}0.135 \\
(0.097)\end{array}$ & & $\begin{array}{c}-0.202^{a} \\
(0.067)\end{array}$ & & $\begin{array}{c}0.276^{a} \\
(0.075)\end{array}$ \\
\hline Constant & $\begin{array}{c}-14.681^{a} \\
(0.047)\end{array}$ & $\begin{array}{c}-14.684^{a} \\
(0.047)\end{array}$ & $\begin{array}{c}-15.384^{a} \\
(0.077)\end{array}$ & $\begin{array}{c}-15.463^{a} \\
(0.082)\end{array}$ & $\begin{array}{c}-15.045^{a} \\
(0.043)\end{array}$ & $\begin{array}{c}-15.060^{a} \\
(0.045)\end{array}$ \\
\hline Observations & 796 & 796 & 896 & 896 & 896 & 896 \\
\hline
\end{tabular}

Estimations run at the regional level, where a region is defined by the grid square computed in G-econ data. Standardized coefficients. Robust standard errors, clustered by region in parentheses. All estimations include year dummies and region fixed effects. ${ }^{c}$ significant at $10 \% ;{ }^{b}$ significant at $5 \%$; ${ }^{a}$ significant at $1 \%$. (1) distance to closest seaport relative to maximum distance computed by country. (2) distance to capital city relative to maximum distance computed by country.

Further evidence in favor of the opportunity cost interpretation can be found in Table 7, in which we show the correlation between the GDP per capita of the region and our different income shock variables. These are based on G-econ data (see section 3.4) which contains for each country the GDP and population of different geographical regions defined by square grids of 100 kilometers. The data is available only for four years (1990, 1995, 2000 and 2005). We regress the log of GDP per capita of the G-econ area on our three shock variables and their interaction with remoteness (columns (1), (3), (5)). The coefficients have the expected sign: a positive external income shock raises GDP per capita, the less so the region is located far away from the seaports. In columns (2), (4) and (6) we further include interaction terms between the shock variables and distance to the capital city in the estimations. The effect of remoteness remains significant at the $1 \%$ level.

\section{Conclusion}

In this paper we use detailed information on the location of conflicts within Sub-Saharan African countries to the study the effect of external shocks both within and across countries. In order to reconcile the seemingly contradictory results found by micro- and macro-level studies, we 
propose a number of alternative ways to identify exogenous income shocks through international trade patterns. First, we improve the usual measure of temporary commodidy shock using a region-specific measure of agricultural specialization. We go also further by considering two long-lasting shocks with the number of banking crises in the country's partners and changes in foreign trade policy through the entry into force of the African Growth Opportunity Act. Second, we combine these shocks with location-specific information reflecting their "natural" level of trade openness.

Our results are manifold. First, at the micro-level, we show that income shocks are generally negatively and significantly correlated with the incidence, intensity and onset of conflicts within location. But, the relationship between external income shocks and conflict is significantly weaker for locations that are naturally less open. Second, at the our country-level, however, we find whatever the considered income shock, we cannot detect any significant effect on conflict incidence or onset, which is consistent with Bazzi and Blattman (2011). Third, our large and long-lasting shocks affect the location of conflict outbreak at the country level. All this findings confirm that conflicts tend to start on average in relatively remote locations, which are by definition inward-oriented and therefore less affected by external shocks. Our results shed light also that the opportunity cost mechanism is more relevant than the state capacity theory to explain the effect of external income.

All in all, our results suggest that external income shocks are important to understand the geography and intensity of ongoing conflicts, but that external income shocks are therefore probably not the main cause of civil war outbreak at the country level. Long-term institutional issues, inequality or ethnic problems are probably more relevant. Income shocks however seem to matter to understand the geography of conflicts, as well as their intensity. The boom in food prices was not the primarily cause of the recent Arab spring, but many analysts emphasized its role in accelerating and magnifying the protests. Likewise, income shocks may act as a "threat multiplier", and certainly explain an important part of the timing, geography and intensity of conflicts around the world. 


\section{References}

Abiad, A., Topalova, P. and Mishra, P. (2011), "How Does Trade Evolve in the Aftermath of Financial Crises?", IMF Working Papers 11/3.

Aviat, A. and Coeurdacier, N. (2007), "The geography of trade in goods and asset holdings", Journal of International Economics, vol. $71 \mathrm{n}^{\circ}$ 1: pp. 22-51.

Baldwin, R. (2009), The Great Trade Collapse: Causes, consequences and prospects, Vox Eu.

Barbieri, K. and Reuveny, R. (2005), "Globalization and Civil War", Journal of Politics.

Bazzi, S. and Blattman, C. (2011), "Economic shocks and conflict: the (Absence of?) Evidence from commodity prices", Mimeo, Yale University.

Besley, T. and Persson, T. (2011), "The Logic of Political Violence", The Quarterly Journal of Economics, vol. 126 n n $^{\circ}$ : pp. 1411-1445.

Besley, T. J. and Persson, T. (2008), "The Incidence of Civil War: Theory and Evidence", NBER Working Papers 14585.

Blattman, C. and Miguel, E. (2010), "Civil War", Journal of Economic Literature, vol. 48 $\mathrm{n}^{\mathrm{o}} 1:$ pp. $3-57$.

Bohlken, A. T. and Sergenti, E. J. (2010), "Economic Growth and Ethnic Violence: An Empirical Investigation of Hindu-Muslim Riots in India", Journal of Peace Research, vol. 47 $\mathrm{n}^{\circ}$ 5: pp. 589-600.

BrüCkner, M. and Ciccone, A. (2010), "International Commodity Prices, Growth and the Outbreak of Civil War in Sub-Saharan Africa", Economic Journal, vol. $120 \mathrm{n}^{\mathrm{o}}$ 544: pp. $519-534$.

Buhaug, H. (2010), "Dude, where's my conflict? LSG, Relative strenght and the location of civil war", Conflict Management and Peace Science, vol. 27 n 2: pp. 107-128.

Buhaug, H., Gleditsch, K., Holtermann, H., Ostby, G. and Tollefsen, A. (2011), "It's the local economy, stupid! Geographic wealth dispersion and conflict outbreak location", Journal of Conflict Resolution, vol. $55 \mathrm{n}^{\circ}$ 5: pp. 814-840. 
Cederman, L.-E., Weidmann, N. B. and Gleditsch, K. S. (2011), "Horizontal Inequalities and Ethnonationalist Civil War: A Global Comparison", American Political Science Review, vol. $105 \mathrm{n}^{\circ}$ 3: pp. 478-495.

Chassang, S. and Padro-I Miquel, G. (2009), "Economic Shocks and civil war", Quarterly Journal of Political Science, vol. $4 \mathrm{n}^{\circ}$ 3: pp. 211-28.

Cotet, A. and Tsui, K. (2010), "Oil and Conflict: What Does the Cross-Country Evidence Really Show?", Mimeo.

Couttenier, M. and Soubeyran, R. (2010), "Drought and Civil War in Sub-Saharan Africa", WP 2010.150, Fondazione Eni Enrico Mattei.

DAL Bó, E. and DAL Bó, E. (2011), "Workers, Warriors and Criminals: Social Conflict in General Equilibrium"”, Journal of the European Economic Association.

Deaton, A. (1999), "Commodity Prices and Growth in Africa", Journal of Economic Perspectives, vol. $13 \mathrm{n}^{\mathrm{o}}$ 3: pp. 23-40.

Dube, O. and Vargas, J. (2011), "Commodity price shocks and civil conflicts: evidence from Colombia", Mimeo, NYU.

Fearon, J. (), Ethnic Mobilization and Ethnic Violence, Oxford University Press.

Fearon, J. (2005), "Primary commodity exports and civil war", Journal of Conflict Resolution, vol. $49 \mathrm{n}^{\mathrm{o}}$ 4: pp. 483-507.

Fearon, J. and Laitin, D. (2003), "Ethnicity, Insurgency and Civil War", American Policial Science Review, vol. 97 n 1 : pp. 75-90.

Frazer, G. and Biesebroeck, J. V. (2010), "Trade Growth under the African Growth and Opportunity Act", The Review of Economics and Statistics, vol. 92 n ${ }^{\circ}$ 1: pp. 128-144.

Garfinkel, M. R. and Skaperdas, S. (2007), "Economics of Conflict: An Overview", Handbook of Defense Economics, vol. 2: pp. 649-709.

Grossman, H. I. (1991), "A General Equilibrium Model of Insurrections", American Economic Review, vol. $81 \mathrm{n}^{\mathrm{o}}$ 4: pp. 912-21. 
HaAvelmo, T. (1954), A study of the theory of economic evolution, Amsterdam: NorthHolland.

Hidalgo, F. D., Naidu, S., Nichter, S. and Richardson, N. (2010), "Economic Determinants of Land Invasions", The Review of Economics and Statistics, vol. $92 \mathrm{n}^{\mathrm{o}}$ 3: pp. $505-523$.

Hirshleifer, J. (1989), "Conflict and rent seeking success functions: ratio vs. difference models of relative success", Public Choice, vol. 63 n 2: pp. 101-12.

JHA, S. (2008), "Trade, Institutions and Religious Tolerance: Evidence from India", Research Papers 2004, Stanford University, Graduate School of Business.

JiA, R. (2011), "Weather shocks, Swett potatoes and peasant revolts in Historical China", Mimeo, IIES.

Lei, Y.-H. and Michaels, G. (2011), "Do Giant Oilfield Discoveries Fuel Internal Armed Conflicts?", CEPR Discussion Papers 8620.

Martin, P., Mayer, T. and Thoenig, M. (2008), "Civil Wars and International Trade", Journal of the European Economic Association, vol. 6 no 2-3: pp. 541-550.

Miguel, E., Satyanath, S. and Sergenti, E. (2004), "Economic Shocks and Civil Conflict: An Instrumental Variables Approach", Journal of Political Economy, vol. 112 no 4: pp. 72553.

Nillesen, E. and Verwimp, P. (2009), "Grievance, Commodity Prices and Rainfall: A Village-level Analysis of Rebel Recruitment in Burundi", HiCN Working Papers 58.

Nordhaus, W., Azam, Q., Corderi, D., Hood, K., Makarova Victor, N., Mohammed, M., Miltner, A. and Weiss, J. (2006), "The G-Econ Database on Gridded Output: Methods and Data", mimeo yale university.

Reinhart, C. M. and Rogoff, K. S. (2011), "From Financial Crash to Debt Crisis", American Economic Review, vol. 101: pp. 1676-1706.

Ross, M. (2006), "A closer look at Oil, Diamonds, and Civil War", Annual Review of Political Science, vol. 9: pp. 265-300. 


\section{$9 \quad$ Appendix}

\subsection{Additional Tables}

Table 8: Descriptive statistics

\begin{tabular}{|c|c|c|c|c|c|}
\hline & Mean & S.D. & $1^{\text {st }}$ Quartile & Median & $3^{\text {rd }}$ Quartile \\
\hline $\operatorname{Pr}($ conflict $)$ & 0.07 & 0.26 & 0.00 & 0.00 & 0.00 \\
\hline \# conflicts & 0.10 & 0.67 & 0.00 & 0.00 & 0.00 \\
\hline$\#$ conflicts (if $>0$ ) & 1.39 & 2.06 & 1.00 & 1.00 & 1.00 \\
\hline Distance to capital (km) & 445.95 & 486.79 & 113.02 & 251.17 & 563.50 \\
\hline Distance to closest port $(\mathrm{km})$ & 788.85 & 472.03 & 226.02 & 1016.57 & 1138.33 \\
\hline Rel. distance to closest port ${ }^{1}$ & 0.66 & 0.27 & 0.50 & 0.74 & 0.87 \\
\hline Rel. distance to capital city ${ }^{1}$ & 0.53 & 0.27 & 0.32 & 0.57 & 0.76 \\
\hline Roughness & 0.15 & 0.14 & 0.05 & 0.09 & 0.19 \\
\hline GDP (1990, PPP adj.) & 0.30 & 0.41 & 0.06 & 0.18 & 0.42 \\
\hline Elevation & 893.86 & 479.69 & 457.46 & 953.87 & 1238.04 \\
\hline ln agr. com. shock & 14.55 & 0.56 & 14.1 & 14.54 & 14.94 \\
\hline Exp. to crises & 0.08 & 0.10 & 0.02 & 0.05 & 0.11 \\
\hline AGOA & 0.14 & 0.34 & 0.00 & 0.00 & 0.00 \\
\hline
\end{tabular}

Note: Source: ACLED, G-econ and authors' computations. The number of observations is $27,404 .{ }^{1}$ relative to maximum distance, computed by country. 
Table 9: Description of Commodities

\begin{tabular}{ccc}
\hline \hline Apples & Ginger & Potatoes \\
Avocados & Grapes & Pulses nes \\
Bambara Beans & Groundnuts in Shell & Pumpkins, Squash, Gourds \\
Bananas & Lentils & Rice, Paddy \\
Barley & Maize & Seed Cotton \\
Beans, Dry & Mangoes, mangosteens, guavas & Sesame Seed \\
Beans, Green & Melonseed & Sorghum \\
Broad Beans, Dry & Millet & Soybeans \\
Broad Beans, Green & Natural Rubber & Sugar Beets \\
Cabbages & Oats & Sugar Cane \\
Cantaloupes\&oth Melons & Oil Palm Fruit & Sunflower Seed \\
Cashew Nuts & Okra & Sweet Potatoes \\
Cassava & Olives & Tang.Mand.Clement.Satsma \\
Chick-Peas & Taro (Coco Yam) \\
Chillies\&Peppers, Green & Onions+Shallots, Green & Tobacco Leaves \\
Citrus Fruit nes & Onions, Dry & Tomatoes \\
Cloves, Whole+Stems & Oranges & Vanilla \\
Cocoa Beans & Peas, Dry & Vegetables Fresh nes \\
Coffee, Green & Peas, Green & Watermelons \\
Cow Peas, Dry & Pepper,White/Long/Black & Wheat \\
Cucumbers and Gherkins & Pigeon Peas & Yams \\
Eggplants & Pimento, Allspice & Yautia (Cocoyam) \\
Fonio & Pineapples & \\
Garlic & Pistachios & \\
\hline \hline
\end{tabular}

Source: FAO AgroStat. 
Table 10: Agricultural commodities shocks and conflicts: Bazzi and Blattman (2011) data

\begin{tabular}{|c|c|c|c|c|c|c|c|c|}
\hline Dep. Var. & \multicolumn{3}{|c|}{ Conflict incidence } & \multicolumn{2}{|c|}{ Conflict onset } & \multicolumn{3}{|c|}{ \# Conflicts } \\
\hline $\begin{array}{l}\text { Estimator } \\
\text { Country spec. trend } \\
\text { Spec. }\end{array}$ & $\begin{array}{c}\text { FE logit } \\
\text { No } \\
(1)\end{array}$ & $\begin{array}{c}\text { FE logit } \\
\text { Yes } \\
(2)\end{array}$ & $\begin{array}{c}\text { FE-LPM } \\
\text { Yes } \\
(3)\end{array}$ & $\begin{array}{c}\text { FE logit } \\
\text { No } \\
(4)\end{array}$ & $\begin{array}{l}\text { FE-LPM } \\
\text { Yes } \\
(5)\end{array}$ & $\begin{array}{l}\text { PPML } \\
\text { No } \\
(6)\end{array}$ & $\begin{array}{l}\text { PPML } \\
\text { Yes } \\
(7)\end{array}$ & $\begin{array}{c}\text { FE-LPM } \\
\text { Yes } \\
(8)\end{array}$ \\
\hline \multicolumn{9}{|l|}{ PANEL A: } \\
\hline ln price shock & $\begin{array}{c}-0.514^{a} \\
(0.101)\end{array}$ & $\begin{array}{c}-0.462^{a} \\
(0.098)\end{array}$ & $\begin{array}{c}-0.022^{a} \\
(0.006)\end{array}$ & $\begin{array}{c}-0.473^{a} \\
(0.098)\end{array}$ & $\begin{array}{c}-0.017^{a} \\
(0.005)\end{array}$ & $\begin{array}{c}-0.398^{a} \\
(0.114)\end{array}$ & $\begin{array}{c}-0.331^{a} \\
(0.103)\end{array}$ & $\begin{array}{c}-0.038^{b} \\
(0.017)\end{array}$ \\
\hline \multicolumn{9}{|l|}{ PANEL B } \\
\hline ln price shock & $\begin{array}{c}-0.901^{a} \\
(0.175)\end{array}$ & $\begin{array}{c}-0.640^{a} \\
(0.165)\end{array}$ & $\begin{array}{c}-0.039^{a} \\
(0.010)\end{array}$ & $\begin{array}{c}-0.892^{a} \\
(0.174)\end{array}$ & $\begin{array}{r}-0.032^{a} \\
(0.009)\end{array}$ & $\begin{array}{c}-1.160^{a} \\
(0.189)\end{array}$ & $\begin{array}{c}-0.881^{a} \\
(0.164)\end{array}$ & $\begin{array}{c}-0.126^{a} \\
(0.026)\end{array}$ \\
\hline ln price shock $\times$ remoteness ${ }^{1}$ & $\begin{array}{c}0.911^{a} \\
(0.324)\end{array}$ & $\begin{array}{c}0.407 \\
(0.282)\end{array}$ & $\begin{array}{c}0.039^{b} \\
(0.018)\end{array}$ & $\begin{array}{c}0.972^{a} \\
(0.317)\end{array}$ & $\begin{array}{c}0.033^{b} \\
(0.014)\end{array}$ & $\begin{array}{l}1.766^{a} \\
(0.456)\end{array}$ & $\begin{array}{l}1.245^{a} \\
(0.368)\end{array}$ & $\begin{array}{c}0.195^{a} \\
(0.048)\end{array}$ \\
\hline
\end{tabular}

Robust standard errors, clustered by location in parentheses. All estimations include year dummies and location fixed effects. ${ }^{c}$ significant at $10 \% ;$ significant at $5 \% ;^{a}$ significant at $1 \%$. Price shock is the change, averaged over the current and two previous years, in the commodity price index as computed by Bazzi and Blattman (2011). ${ }^{1}$ distance to closest seaport relative to maximum distance computed by country. The number of observations is 27,378 in conflict incidence and intensity estimations, 26,817 in conflict onset estimations. 
Table 11: Agricultural commodities shocks and conflicts: robustness (Sample II)

\begin{tabular}{|c|c|c|c|c|c|c|c|c|c|}
\hline Dep. Var. & \multicolumn{3}{|c|}{ Conflict incidence } & \multicolumn{3}{|c|}{ Conflict onset } & \multicolumn{3}{|c|}{ \# Conflicts } \\
\hline $\begin{array}{l}\text { Estimator } \\
\text { Country spec. trend }\end{array}$ & $\begin{array}{c}\text { FE logit } \\
\text { No } \\
(1)\end{array}$ & $\begin{array}{c}\text { FE logit } \\
\text { Yes } \\
(2)\end{array}$ & $\begin{array}{c}\text { FE-LPM } \\
\text { Yes } \\
(3)\end{array}$ & $\begin{array}{c}\text { FE logit } \\
\text { No } \\
(4)\end{array}$ & $\begin{array}{c}\text { FE logit } \\
\text { Yes } \\
(5)\end{array}$ & $\begin{array}{c}\text { FE-LPM } \\
\text { Yes } \\
(6)\end{array}$ & $\begin{array}{l}\text { PPML } \\
\text { No } \\
(7)\end{array}$ & $\begin{array}{c}\text { PPML } \\
\text { Yes } \\
(8)\end{array}$ & $\begin{array}{c}\text { FE-LPM } \\
\text { Yes } \\
(9)\end{array}$ \\
\hline \multicolumn{10}{|l|}{$\underline{\text { PANEL A }}$} \\
\hline ln agr. shock & $\begin{array}{l}-2.127^{a} \\
(0.296)\end{array}$ & $\begin{array}{l}-1.041^{a} \\
(0.375)\end{array}$ & $\begin{array}{l}-0.110^{b} \\
(0.046)\end{array}$ & $\begin{array}{l}-1.863^{a} \\
(0.287)\end{array}$ & $\begin{array}{l}-0.703^{c} \\
(0.402)\end{array}$ & $\begin{array}{l}-0.097^{b} \\
(0.044)\end{array}$ & $\begin{array}{l}-3.065^{a} \\
(0.516)\end{array}$ & $\begin{array}{l}-1.668^{a} \\
(0.528)\end{array}$ & $\begin{array}{l}-0.780^{b} \\
(0.326)\end{array}$ \\
\hline \multicolumn{10}{|l|}{$\underline{\text { PANEL B }}$} \\
\hline ln agr. shock & $\begin{array}{l}-5.579^{a} \\
(0.432)\end{array}$ & $\begin{array}{l}-2.051^{a} \\
(0.535)\end{array}$ & $\begin{array}{l}-0.125^{b} \\
(0.063)\end{array}$ & $\begin{array}{l}-5.079^{a} \\
(0.419)\end{array}$ & $\begin{array}{l}-1.404^{b} \\
(0.572)\end{array}$ & $\begin{array}{l}-0.151^{a} \\
(0.054)\end{array}$ & $\begin{array}{l}-5.605^{a} \\
(0.748)\end{array}$ & $\begin{array}{l}-1.986^{b} \\
(0.822)\end{array}$ & $\begin{array}{l}-0.665 \\
(0.544)\end{array}$ \\
\hline ln agr. shock $\times$ remoteness ${ }^{1}$ & $\begin{array}{l}5.059^{a} \\
(0.476)\end{array}$ & $\begin{array}{c}1.514^{b} \\
(0.605)\end{array}$ & $\begin{array}{c}0.022 \\
(0.063)\end{array}$ & $\begin{array}{l}4.683^{a} \\
(0.469)\end{array}$ & $\begin{array}{c}1.043 \\
(0.645)\end{array}$ & $\begin{array}{c}0.081 \\
(0.052)\end{array}$ & $\begin{array}{l}4.023^{a} \\
(0.834)\end{array}$ & $\begin{array}{c}0.500 \\
(0.845)\end{array}$ & $\begin{array}{l}-0.172 \\
(0.463)\end{array}$ \\
\hline \multicolumn{10}{|l|}{$\underline{\text { PANEL C }}$} \\
\hline ln price shock & $\begin{array}{l}0.510^{a} \\
(0.182)\end{array}$ & $\begin{array}{l}-1.121^{a} \\
(0.229)\end{array}$ & $\begin{array}{l}-0.165^{a} \\
(0.028)\end{array}$ & $\begin{array}{l}0.403^{c} \\
(0.220)\end{array}$ & $\begin{array}{l}-0.756^{a} \\
(0.263)\end{array}$ & $\begin{array}{l}-0.123^{a} \\
(0.029)\end{array}$ & $\begin{array}{l}-0.331 \\
(0.556)\end{array}$ & $\begin{array}{l}-2.166^{a} \\
(0.537)\end{array}$ & $\begin{array}{l}-1.775^{a} \\
(0.592)\end{array}$ \\
\hline ln price shock $\times$ remoteness ${ }^{1}$ & $\begin{array}{l}1.125^{a} \\
(0.276)\end{array}$ & $\begin{array}{l}1.636^{a} \\
(0.312)\end{array}$ & $\begin{array}{c}0.170^{a} \\
(0.033)\end{array}$ & $\begin{array}{l}0.964^{a} \\
(0.307)\end{array}$ & $\begin{array}{l}1.380^{a} \\
(0.346)\end{array}$ & $\begin{array}{c}0.137^{a} \\
(0.032)\end{array}$ & $\begin{array}{l}1.231^{c} \\
(0.712)\end{array}$ & $\begin{array}{l}1.279^{b} \\
(0.620)\end{array}$ & $\begin{array}{l}1.132^{b} \\
(0.440)\end{array}$ \\
\hline
\end{tabular}

Robust standard errors, clustered by location (except in FE logit estimations) in parentheses. All estimations include year dummies and location fixed effects. ${ }^{c}$ significant at $10 \% ;^{b}$ significant at $5 \% ;^{a}$ significant at $1 \%$. Price shock is the change, averaged over the current and two previous years, in the commodity price index as computed by Bazzi and Blattman (2011). ${ }^{1}$ distance to closest seaport relative to maximum distance computed by country. The number of observations is 31,987 in conflict incidence and intensity estimations, 28,758 in conflict onset estimations in panel A and B (respectively 39,974 and 36,004 in Panel C). 
Table 12: Exposure to crises and conflicts: additional controls

\begin{tabular}{|c|c|c|c|c|c|c|c|c|}
\hline \multirow{2}{*}{$\begin{array}{l}\text { Dep. Var. } \\
\text { Estimator } \\
\text { Country spec. trend } \\
\text { Spec. }\end{array}$} & \multicolumn{3}{|c|}{ Conflict incidence } & \multicolumn{2}{|c|}{ Conflict onset } & \multicolumn{3}{|c|}{ \# Conflicts } \\
\hline & $\begin{array}{c}\text { FE logit } \\
\text { No } \\
(1)\end{array}$ & $\begin{array}{c}\text { FE logit } \\
\text { Yes } \\
(2)\end{array}$ & $\begin{array}{c}\text { FE-LPM } \\
\text { Yes } \\
(3)\end{array}$ & $\begin{array}{c}\text { FE logit } \\
\text { No } \\
(4)\end{array}$ & $\begin{array}{c}\text { FE-LPM } \\
\text { Yes } \\
(5)\end{array}$ & $\begin{array}{l}\text { PPML } \\
\text { No } \\
(6)\end{array}$ & $\begin{array}{l}\text { PPML } \\
\text { Yes } \\
(7)\end{array}$ & $\begin{array}{c}\text { FE-LPM } \\
\text { Yes } \\
(8)\end{array}$ \\
\hline \multicolumn{9}{|l|}{ PANEL A } \\
\hline Exposure to crises & $\begin{array}{c}10.509^{a} \\
(1.222)\end{array}$ & $\begin{array}{l}11.606^{a} \\
(1.273)\end{array}$ & $\begin{array}{c}0.924^{a} \\
(0.105)\end{array}$ & $\begin{array}{l}11.239^{a} \\
(1.437)\end{array}$ & $\begin{array}{l}0.754^{a} \\
(0.099)\end{array}$ & $\begin{array}{c}6.432^{a} \\
(2.218)\end{array}$ & $\begin{array}{l}6.623^{a} \\
(2.272)\end{array}$ & $\begin{array}{l}1.622^{a} \\
(0.301)\end{array}$ \\
\hline Exp. to crises $\times$ remoteness $(2)$ & $\begin{array}{c}-1.828^{a} \\
(0.207)\end{array}$ & $\begin{array}{c}-2.049^{a} \\
(0.215)\end{array}$ & $\begin{array}{c}-0.166^{a} \\
(0.018)\end{array}$ & $\begin{array}{c}-1.862^{a} \\
(0.233)\end{array}$ & $\begin{array}{c}-0.129^{a} \\
(0.016)\end{array}$ & $\begin{array}{c}-1.094^{a} \\
(0.347)\end{array}$ & $\begin{array}{r}-1.142^{a} \\
(0.359)\end{array}$ & $\begin{array}{c}-0.288^{a} \\
(0.046)\end{array}$ \\
\hline \multicolumn{9}{|l|}{ PANEL B } \\
\hline Exposure to crises & $\begin{array}{c}0.216 \\
(0.588)\end{array}$ & $\begin{array}{c}-0.144 \\
(0.600)\end{array}$ & $\begin{array}{c}-0.022 \\
(0.043)\end{array}$ & $\begin{array}{c}0.755 \\
(0.638)\end{array}$ & $\begin{array}{c}0.023 \\
(0.038)\end{array}$ & $\begin{array}{c}0.353 \\
(0.761)\end{array}$ & $\begin{array}{c}0.090 \\
(0.797)\end{array}$ & $\begin{array}{c}-0.045 \\
(0.126)\end{array}$ \\
\hline Exp. to crises $\times$ remoteness $(3)$ & $\begin{array}{l}-1.507 \\
(2.547)\end{array}$ & $\begin{array}{c}-0.193 \\
(2.661)\end{array}$ & $\begin{array}{l}-0.084 \\
(0.163)\end{array}$ & $\begin{array}{c}-2.408 \\
(2.598)\end{array}$ & $\begin{array}{c}-0.125 \\
(0.130)\end{array}$ & $\begin{array}{c}0.755 \\
(3.406)\end{array}$ & $\begin{array}{c}2.958 \\
(3.652)\end{array}$ & $\begin{array}{c}0.075 \\
(0.444)\end{array}$ \\
\hline \multicolumn{9}{|l|}{ PANEL C } \\
\hline Exp. to crises & $\begin{array}{c}2.561^{a} \\
(0.887)\end{array}$ & $\begin{array}{c}2.933^{a} \\
(0.956)\end{array}$ & $\begin{array}{c}0.172^{b} \\
(0.069)\end{array}$ & $\begin{array}{l}2.617^{a} \\
(1.010)\end{array}$ & $\begin{array}{c}0.141^{b} \\
(0.061)\end{array}$ & $\begin{array}{c}3.290^{a} \\
(1.013)\end{array}$ & $\begin{array}{c}3.463^{a} \\
(1.123)\end{array}$ & $\begin{array}{c}0.468^{b} \\
(0.211)\end{array}$ \\
\hline Exp. to crises $\times$ remoteness $(1)$ & $\begin{array}{c}-4.873^{a} \\
(1.531)\end{array}$ & $\begin{array}{c}-7.687^{a} \\
(1.644)\end{array}$ & $\begin{array}{c}-0.493^{a} \\
(0.105)\end{array}$ & $\begin{array}{c}-4.210^{a} \\
(1.479)\end{array}$ & $\begin{array}{c}-0.322^{a} \\
(0.080)\end{array}$ & $\begin{array}{l}-2.827^{c} \\
(1.627)\end{array}$ & $\begin{array}{c}-4.845^{b} \\
(1.936)\end{array}$ & $\begin{array}{c}-0.728^{b} \\
(0.306)\end{array}$ \\
\hline Exp. to crises $\times \ln$ dist. to cap. & $\begin{array}{c}-2.939^{c} \\
(1.637)\end{array}$ & $\begin{array}{c}-1.901 \\
(1.686)\end{array}$ & $\begin{array}{c}-0.100 \\
(0.110)\end{array}$ & $\begin{array}{c}-3.495^{b} \\
(1.419)\end{array}$ & $\begin{array}{c}-0.131^{c} \\
(0.073)\end{array}$ & $\begin{array}{c}-6.156^{a} \\
(2.013)\end{array}$ & $\begin{array}{l}-5.218^{b} \\
(2.225)\end{array}$ & $\begin{array}{c}-0.657 \\
(0.529)\end{array}$ \\
\hline Exp. to crises $\times \ln$ GDP area & $\begin{array}{c}0.512^{b} \\
(0.257)\end{array}$ & $\begin{array}{c}0.325 \\
(0.268)\end{array}$ & $\begin{array}{c}0.036^{b} \\
(0.017)\end{array}$ & $\begin{array}{c}0.589^{a} \\
(0.215)\end{array}$ & $\begin{array}{c}0.029^{a} \\
(0.011)\end{array}$ & $\begin{array}{c}0.733^{b} \\
(0.357)\end{array}$ & $\begin{array}{c}0.615^{c} \\
(0.359)\end{array}$ & $\begin{array}{c}0.077 \\
(0.084)\end{array}$ \\
\hline Exp. to crises $\times$ border & $\begin{array}{l}3.040^{a} \\
(0.833)\end{array}$ & $\begin{array}{c}2.656^{a} \\
(0.891)\end{array}$ & $\begin{array}{c}0.179^{a} \\
(0.044)\end{array}$ & $\begin{array}{c}3.842^{a} \\
(0.724)\end{array}$ & $\begin{array}{c}0.179^{a} \\
(0.032)\end{array}$ & $\begin{array}{c}4.767^{a} \\
(0.939)\end{array}$ & $\begin{array}{c}4.552^{a} \\
(1.046)\end{array}$ & $\begin{array}{c}0.563^{a} \\
(0.134)\end{array}$ \\
\hline Exp. to crises $\times$ nat. ress. & $\begin{array}{l}4.116^{a} \\
(0.705)\end{array}$ & $\begin{array}{l}4.350^{a} \\
(0.719)\end{array}$ & $\begin{array}{l}0.313^{a} \\
(0.053)\end{array}$ & $\begin{array}{l}4.299^{a} \\
(0.730)\end{array}$ & $\begin{array}{c}0.266^{a} \\
(0.045)\end{array}$ & $\begin{array}{l}3.422^{a} \\
(0.758)\end{array}$ & $\begin{array}{l}3.517^{a} \\
(0.840)\end{array}$ & $\begin{array}{c}0.508^{a} \\
(0.139)\end{array}$ \\
\hline
\end{tabular}

Robust standard errors, clustered by location (except in FE logit estimations) in parentheses. All estimations include year dummies and location fixed effects. ${ }^{c}$ significant at $10 \% ;^{b}$ significant at $5 \% ;^{a}$ significant at $1 \%$. (1) distance to closest seaport relative to maximum distance computed by country. (2) In distance to closest seaport. (3) roughness of terrain from G-econ; rel. dist. to cap.: distance to capital city relative to maximum distance computed by country. In GDP area: GDP of the area in 2000, from G-econ; nat. ress.: dummy which equals 1 if the location is within 100km of an oil or diamond field. The number of observations is 27,352 in conflict incidence and intensity estimations, 26,691 in conflict onset estimations. 
Table 13: Exposure to crises and conflicts: robustness (Sample II)

\begin{tabular}{|c|c|c|c|c|c|c|c|c|}
\hline Dep. Var. & \multicolumn{3}{|c|}{ Conflict incidence } & \multicolumn{2}{|c|}{ Conflict onset } & \multicolumn{3}{|c|}{ \# Conflicts } \\
\hline $\begin{array}{l}\text { Estimator } \\
\text { Country spec. trend } \\
\text { Spec. }\end{array}$ & $\begin{array}{l}\text { FE logit } \\
\text { No } \\
(1)\end{array}$ & $\begin{array}{c}\text { FE logit } \\
\text { Yes } \\
(2)\end{array}$ & $\begin{array}{c}\text { FE-LPM } \\
\text { Yes } \\
(3)\end{array}$ & $\begin{array}{l}\text { FE logit } \\
\text { No } \\
(4)\end{array}$ & $\begin{array}{l}\text { FE-LPM } \\
\text { Yes } \\
\quad(5)\end{array}$ & $\begin{array}{l}\text { PPML } \\
\text { No } \\
(6)\end{array}$ & $\begin{array}{l}\text { PPML } \\
\text { Yes } \\
(7)\end{array}$ & $\begin{array}{c}\text { FE-LPM } \\
\text { Yes } \\
(8)\end{array}$ \\
\hline \multicolumn{9}{|l|}{ PANEL A } \\
\hline Exposure to crises & $\begin{array}{c}-0.683^{a} \\
(0.120)\end{array}$ & $\begin{array}{c}0.334^{c} \\
(0.199)\end{array}$ & $\begin{array}{c}0.029^{c} \\
(0.016)\end{array}$ & $\begin{array}{c}-0.848^{a} \\
(0.116)\end{array}$ & $\begin{array}{c}0.017 \\
(0.015)\end{array}$ & $\begin{array}{c}-0.311 \\
(0.223)\end{array}$ & $\begin{array}{l}1.057^{a} \\
(0.279)\end{array}$ & $\begin{array}{c}0.263^{a} \\
(0.087)\end{array}$ \\
\hline \multicolumn{9}{|l|}{ PANEL B } \\
\hline Exposure to crises & $\begin{array}{c}0.473^{a} \\
(0.177)\end{array}$ & $\begin{array}{c}2.213^{a} \\
(0.309)\end{array}$ & $\begin{array}{c}0.175^{a} \\
(0.020)\end{array}$ & $\begin{array}{c}0.127 \\
(0.182)\end{array}$ & $\begin{array}{c}0.117^{a} \\
(0.019)\end{array}$ & $\begin{array}{c}0.814^{b} \\
(0.353)\end{array}$ & $\begin{array}{l}2.911^{a} \\
(0.580)\end{array}$ & $\begin{array}{c}0.850^{a} \\
(0.169)\end{array}$ \\
\hline Exp. to crises $\times$ remoteness $^{1}$ & $\begin{array}{l}-1.658^{a} \\
(0.206)\end{array}$ & $\begin{array}{l}-2.780^{a} \\
(0.352)\end{array}$ & $\begin{array}{l}-0.225^{a} \\
(0.019)\end{array}$ & $\begin{array}{r}-1.382^{a} \\
(0.210)\end{array}$ & $\begin{array}{r}-0.154^{a} \\
(0.016)\end{array}$ & $\begin{array}{l}-1.676^{a} \\
(0.413)\end{array}$ & $\begin{array}{l}-2.834^{a} \\
(0.745)\end{array}$ & $\begin{array}{c}-0.908^{a} \\
(0.172)\end{array}$ \\
\hline
\end{tabular}

Robust standard errors, clustered by location (except in FE logit estimations) in parentheses. All estimations include year dummies and location fixed effects. ${ }^{c}$ significant at $10 \% ;^{b}$ significant at $5 \% ;^{a}$ significant at $1 \% .{ }^{1}$ distance to closest seaport relative to maximum distance computed by country. The number of observations is 57,022 in conflict incidence and intensity estimations, 52,176 in conflict onset estimations. 
Table 14: AGOA and conflicts: additional controls

\begin{tabular}{|c|c|c|c|c|c|c|c|c|}
\hline \multirow{2}{*}{$\begin{array}{l}\text { Dep. Var. } \\
\text { Estimator } \\
\text { Country spec. trend } \\
\text { Spec. }\end{array}$} & \multicolumn{3}{|c|}{ Conflict incidence } & \multicolumn{2}{|c|}{ Conflict onset } & \multicolumn{3}{|c|}{ \# Conflicts } \\
\hline & $\begin{array}{c}\text { FE logit } \\
\text { No } \\
(1)\end{array}$ & $\begin{array}{c}\text { FE logit } \\
\text { Yes } \\
(2)\end{array}$ & $\begin{array}{c}\text { FE-LPM } \\
\text { Yes } \\
(3)\end{array}$ & $\begin{array}{c}\text { FE logit } \\
\text { No } \\
(4)\end{array}$ & $\begin{array}{c}\text { FE-LPM } \\
\text { Yes } \\
(5)\end{array}$ & $\begin{array}{l}\text { PPML } \\
\text { No } \\
(6)\end{array}$ & $\begin{array}{l}\text { PPML } \\
\text { Yes } \\
(7)\end{array}$ & $\begin{array}{c}\text { FE-LPM } \\
\text { Yes } \\
(8)\end{array}$ \\
\hline \multicolumn{9}{|l|}{$\underline{\text { PANEL A }}$} \\
\hline AGOA dummy & $\begin{array}{r}-7.149^{a} \\
(0.964)\end{array}$ & $\begin{array}{r}-9.425^{a} \\
(1.146)\end{array}$ & $\begin{array}{c}-0.300^{a} \\
(0.034)\end{array}$ & $\begin{array}{l}-6.531^{a} \\
(0.871)\end{array}$ & $\begin{array}{c}-0.219^{a} \\
(0.022)\end{array}$ & $\begin{array}{l}-8.760^{a} \\
(1.259)\end{array}$ & $\begin{array}{c}-10.455^{a} \\
(1.434)\end{array}$ & $\begin{array}{c}-0.808^{a} \\
(0.184)\end{array}$ \\
\hline AGOA $\times$ remoteness $(2)$ & $\begin{array}{l}1.003^{a} \\
(0.141)\end{array}$ & $\begin{array}{l}1.370^{a} \\
(0.169)\end{array}$ & $\begin{array}{l}0.043^{a} \\
(0.005)\end{array}$ & $\begin{array}{l}0.919^{a} \\
(0.127)\end{array}$ & $\begin{array}{l}0.031^{a} \\
(0.004)\end{array}$ & $\begin{array}{l}1.211^{a} \\
(0.187)\end{array}$ & $\begin{array}{l}1.466^{a} \\
(0.220)\end{array}$ & $\begin{array}{l}0.103^{a} \\
(0.030)\end{array}$ \\
\hline \multicolumn{9}{|l|}{ PANEL B } \\
\hline AGOA dummy & $\begin{array}{l}-0.550^{a} \\
(0.135)\end{array}$ & $\begin{array}{l}-0.338^{b} \\
(0.142)\end{array}$ & $\begin{array}{r}-0.037^{a} \\
(0.012)\end{array}$ & $\begin{array}{l}-0.502^{a} \\
(0.126)\end{array}$ & $\begin{array}{l}-0.029^{a} \\
(0.009)\end{array}$ & $\begin{array}{l}-0.724^{a} \\
(0.185)\end{array}$ & $\begin{array}{l}-0.660^{a} \\
(0.205)\end{array}$ & $\begin{array}{l}-0.169^{a} \\
(0.055)\end{array}$ \\
\hline AGOA $\times$ remoteness $(3)$ & $\begin{array}{c}0.404 \\
(0.580)\end{array}$ & $\begin{array}{l}-0.007 \\
(0.653)\end{array}$ & $\begin{array}{c}0.021 \\
(0.039)\end{array}$ & $\begin{array}{c}0.423 \\
(0.550)\end{array}$ & $\begin{array}{c}0.023 \\
(0.031)\end{array}$ & $\begin{array}{c}0.520 \\
(0.730)\end{array}$ & $\begin{array}{l}-0.135 \\
(0.833)\end{array}$ & $\begin{array}{c}0.048 \\
(0.111)\end{array}$ \\
\hline \multicolumn{9}{|l|}{ PANEL C } \\
\hline AGOA & $\begin{array}{r}-2.962^{a} \\
(0.465)\end{array}$ & $\begin{array}{l}-4.953^{a} \\
(0.741)\end{array}$ & $\begin{array}{c}-0.154^{a} \\
(0.019)\end{array}$ & $\begin{array}{l}-2.333^{a} \\
(0.398)\end{array}$ & $\begin{array}{c}-0.107^{a} \\
(0.014)\end{array}$ & $\begin{array}{r}-4.332^{a} \\
(0.701)\end{array}$ & $\begin{array}{l}-6.854^{a} \\
(1.021)\end{array}$ & $\begin{array}{l}-0.456^{a} \\
(0.080)\end{array}$ \\
\hline AGOA $\times$ remoteness $(1)$ & $\begin{array}{l}2.595^{a} \\
(0.633)\end{array}$ & $\begin{array}{l}6.587^{a} \\
(1.043)\end{array}$ & $\begin{array}{c}0.166^{a} \\
(0.026)\end{array}$ & $\begin{array}{l}1.937^{a} \\
(0.571)\end{array}$ & $\begin{array}{c}0.110^{a} \\
(0.020)\end{array}$ & $\begin{array}{l}4.145^{a} \\
(0.864)\end{array}$ & $\begin{array}{l}8.651^{a} \\
(1.397)\end{array}$ & $\begin{array}{l}0.388^{a} \\
(0.080)\end{array}$ \\
\hline AGOA $\times \ln$ dist. to cap. & $\begin{array}{c}0.657 \\
(0.436)\end{array}$ & $\begin{array}{l}-0.400 \\
(0.543)\end{array}$ & $\begin{array}{c}0.042 \\
(0.029)\end{array}$ & $\begin{array}{c}0.731^{c} \\
(0.403)\end{array}$ & $\begin{array}{c}0.043^{b} \\
(0.021)\end{array}$ & $\begin{array}{c}0.567 \\
(0.505)\end{array}$ & $\begin{array}{l}-0.754 \\
(0.647)\end{array}$ & $\begin{array}{c}0.116 \\
(0.115)\end{array}$ \\
\hline AGOA $\times \ln$ GDP area & $\begin{array}{c}-0.149^{b} \\
(0.061)\end{array}$ & $\begin{array}{c}-0.026 \\
(0.070)\end{array}$ & $\begin{array}{l}-0.001 \\
(0.005)\end{array}$ & $\begin{array}{l}-0.073 \\
(0.054)\end{array}$ & $\begin{array}{c}0.002 \\
(0.003)\end{array}$ & $\begin{array}{r}-0.182^{a} \\
(0.067)\end{array}$ & $\begin{array}{l}-0.099 \\
(0.076)\end{array}$ & $\begin{array}{l}-0.006 \\
(0.017)\end{array}$ \\
\hline AGOA $\times$ border & $\begin{array}{c}0.147 \\
(0.202)\end{array}$ & $\begin{array}{c}0.469^{b} \\
(0.238)\end{array}$ & $\begin{array}{c}0.015 \\
(0.013)\end{array}$ & $\begin{array}{c}0.191 \\
(0.180)\end{array}$ & $\begin{array}{c}0.012 \\
(0.010)\end{array}$ & $\begin{array}{c}0.007 \\
(0.233)\end{array}$ & $\begin{array}{c}0.467 \\
(0.298)\end{array}$ & $\begin{array}{c}0.015 \\
(0.037)\end{array}$ \\
\hline Exp. to crises $\times$ nat. ress. & $\begin{array}{l}-2.823^{a} \\
(0.596)\end{array}$ & $\begin{array}{r}-3.197^{a} \\
(0.724)\end{array}$ & $\begin{array}{c}-0.096^{a} \\
(0.016)\end{array}$ & $\begin{array}{l}-2.646^{a} \\
(0.559)\end{array}$ & $\begin{array}{r}-0.077^{a} \\
(0.011)\end{array}$ & $\begin{array}{l}-3.129^{a} \\
(0.632)\end{array}$ & $\begin{array}{r}-3.607^{a} \\
(0.734)\end{array}$ & $\begin{array}{l}-0.191^{a} \\
(0.065)\end{array}$ \\
\hline
\end{tabular}

Robust standard errors, clustered by location (except in FE logit estimations) in parentheses. All estimations include year dummies and location fixed effects. ${ }^{c}$ significant at $10 \% ;{ }^{b}$ significant at $5 \% ;{ }^{a}$ significant at $1 \%$. (1) distance to closest seaport relative to maximum distance computed by country. (2) ln distance to closest seaport. (3) roughness of terrain from G-econ; rel. dist. to cap.: distance to capital city relative to maximum distance computed by country. ln GDP area: GDP of the area in 2000, from G-econ; nat. ress.: dummy which equals 1 if the location is within $100 \mathrm{~km}$ of an oil or diamond field. The number of observations is 27,378 in conflict incidence and intensity estimations, 26,817 in conflict onset estimations. 
Table 15: AGOA and conflicts: robustness (Sample II)

\begin{tabular}{|c|c|c|c|c|c|c|c|c|}
\hline Dep. Var. & \multicolumn{3}{|c|}{ Conflict incidence } & \multicolumn{2}{|c|}{ Conflict onset } & \multicolumn{3}{|c|}{ \# Conflicts } \\
\hline $\begin{array}{l}\text { Estimator } \\
\text { Country spec. trend } \\
\text { Spec. }\end{array}$ & $\begin{array}{c}\text { FE logit } \\
\text { No } \\
(1)\end{array}$ & $\begin{array}{l}\text { FE logit } \\
\text { Yes } \\
(2)\end{array}$ & $\begin{array}{l}\text { FE-LPM } \\
\text { Yes } \\
(3)\end{array}$ & $\begin{array}{c}\text { FE logit } \\
\text { No } \\
(4)\end{array}$ & $\begin{array}{l}\text { FE-LPM } \\
\text { Yes } \\
(5)\end{array}$ & $\begin{array}{l}\text { PPML } \\
\text { No } \\
(6)\end{array}$ & $\begin{array}{l}\text { PPML } \\
\text { Yes } \\
(7)\end{array}$ & $\begin{array}{c}\text { FE-LPM } \\
\text { Yes } \\
(8)\end{array}$ \\
\hline \multicolumn{9}{|l|}{ PANEL A } \\
\hline AGOA dummy & $\begin{array}{l}-0.676^{a} \\
(0.054)\end{array}$ & $\begin{array}{l}-0.469^{a} \\
(0.061)\end{array}$ & $\begin{array}{l}-0.040^{a} \\
(0.006)\end{array}$ & $\begin{array}{l}-0.626^{a} \\
(0.051)\end{array}$ & $\begin{array}{l}-0.043^{a} \\
(0.005)\end{array}$ & $\begin{array}{l}-0.576^{a} \\
(0.104)\end{array}$ & $\begin{array}{l}-0.383^{a} \\
(0.102)\end{array}$ & $\begin{array}{l}-0.143^{a} \\
(0.031)\end{array}$ \\
\hline AGOA $\times$ Exposure & $\begin{array}{l}-5.178^{a} \\
(0.242)\end{array}$ & $\begin{array}{l}-6.354^{a} \\
(0.565)\end{array}$ & $\begin{array}{l}-0.480^{a} \\
(0.030)\end{array}$ & $\begin{array}{l}-4.537^{a} \\
(0.218)\end{array}$ & $\begin{array}{l}-0.450^{a} \\
(0.025)\end{array}$ & $\begin{array}{r}-4.252^{a} \\
(0.428)\end{array}$ & $\begin{array}{l}-3.698^{a} \\
(0.616)\end{array}$ & $\begin{array}{l}-1.009^{a} \\
(0.245)\end{array}$ \\
\hline \multicolumn{9}{|l|}{ PANEL B } \\
\hline AGOA dummy & $\begin{array}{l}-0.845^{a} \\
(0.053)\end{array}$ & $\begin{array}{r}-0.579^{a} \\
(0.062)\end{array}$ & $\begin{array}{l}-0.052^{a} \\
(0.006)\end{array}$ & $\begin{array}{l}-0.740^{a} \\
(0.051)\end{array}$ & $\begin{array}{l}-0.045^{a} \\
(0.005)\end{array}$ & $\begin{array}{l}-0.713^{a} \\
(0.093)\end{array}$ & $\begin{array}{l}-0.428^{a} \\
(0.089)\end{array}$ & $\begin{array}{l}-0.172^{a} \\
(0.031)\end{array}$ \\
\hline $\mathrm{AGOA} \times \ln$ dist. to $\mathrm{US}$ & $\begin{array}{l}5.118^{a} \\
(0.397)\end{array}$ & $\begin{array}{c}6.247^{a} \\
(0.497)\end{array}$ & $\begin{array}{l}0.545^{a} \\
(0.027)\end{array}$ & $\begin{array}{l}4.825^{a} \\
(0.372)\end{array}$ & $\begin{array}{l}0.469^{a} \\
(0.023)\end{array}$ & $\begin{array}{l}5.553^{a} \\
(0.719)\end{array}$ & $\begin{array}{l}5.539^{a} \\
(0.702)\end{array}$ & $\begin{array}{l}2.041^{a} \\
(0.237)\end{array}$ \\
\hline \multicolumn{9}{|l|}{ PANEL C } \\
\hline $\begin{array}{l}\text { main } \\
\text { AGOA dummy }\end{array}$ & $\begin{array}{l}-2.602^{a} \\
(0.134)\end{array}$ & $\begin{array}{l}-1.910^{a} \\
(0.203)\end{array}$ & $\begin{array}{l}-0.161^{a} \\
(0.013)\end{array}$ & $\begin{array}{l}-2.436^{a} \\
(0.132)\end{array}$ & $\begin{array}{l}-0.146^{a} \\
(0.010)\end{array}$ & $\begin{array}{l}-2.379^{a} \\
(0.218)\end{array}$ & $\begin{array}{l}-1.377^{a} \\
(0.291)\end{array}$ & $\begin{array}{l}-0.539^{a} \\
(0.147)\end{array}$ \\
\hline AGOA $\times$ remoteness $^{1}$ & $\begin{array}{l}2.578^{a} \\
(0.171)\end{array}$ & $\begin{array}{c}2.012^{a} \\
(0.261)\end{array}$ & $\begin{array}{c}0.154^{a} \\
(0.017)\end{array}$ & $\begin{array}{c}2.483^{a} \\
(0.170)\end{array}$ & $\begin{array}{c}0.143^{a} \\
(0.013)\end{array}$ & $\begin{array}{l}2.476^{a} \\
(0.285)\end{array}$ & $\begin{array}{l}1.423^{a} \\
(0.371)\end{array}$ & $\begin{array}{c}0.523^{a} \\
(0.191)\end{array}$ \\
\hline
\end{tabular}

Robust standard errors, clustered by location (except in FE logit estimations) in parentheses. All estimations include year dummies and location fixed effects. ${ }^{c}$ significant at $10 \% ;^{b}$ significant at $5 \% ;^{a}$ significant at $1 \% .{ }^{1}$ distance to closest seaport relative to maximum distance computed by country. The number of observations is 57,022 in conflict incidence and intensity estimations, 52,176 in conflict onset estimations. 
Table 16: Shocks and conflicts: $1 \times 1$ degree cells

\begin{tabular}{|c|c|c|c|c|c|c|}
\hline Dep. Var. & $\operatorname{Pr}($ conflict $>0)$ & \# Conflicts & $\operatorname{Pr}($ conflict $>0)$ & \# Conflicts & $\operatorname{Pr}($ conflict $>0)$ & \# Conflicts \\
\hline $\begin{array}{l}\text { Estimator } \\
\text { Shock }\end{array}$ & \multicolumn{2}{|c|}{ Commodities } & \multicolumn{2}{|c|}{ Crises } & \multicolumn{2}{|c|}{ AGOA } \\
\hline Shock & $\begin{array}{l}-2.881^{a} \\
(0.847)\end{array}$ & $\begin{array}{c}-3.376^{a} \\
(0.693)\end{array}$ & $\begin{array}{c}3.234^{b} \\
(1.385)\end{array}$ & $\begin{array}{l}4.773^{a} \\
(1.761)\end{array}$ & $\begin{array}{l}-3.508^{a} \\
(0.823)\end{array}$ & $\begin{array}{l}-6.414^{a} \\
(1.649)\end{array}$ \\
\hline Shock $\times$ Remoteness $^{1}$ & $\begin{array}{c}0.734 \\
(0.929)\end{array}$ & $\begin{array}{l}3.250^{a} \\
(0.785)\end{array}$ & $\begin{array}{c}-7.520^{a} \\
(2.024)\end{array}$ & $\begin{array}{c}-8.268^{a} \\
(2.808)\end{array}$ & $\begin{array}{c}3.665^{a} \\
(1.132)\end{array}$ & $\begin{array}{c}7.682^{a} \\
(2.035)\end{array}$ \\
\hline Observations & 3383 & 3383 & 6422 & 6422 & 6422 & 6422 \\
\hline
\end{tabular}

Robust standard errors, clustered by location (except in FE logit estimations) in parentheses. All estimations include year dummies, location fixed effects and country-specific time-trends. ${ }^{c}$ significant at $10 \% ;{ }^{b}$ significant at $5 \% ;{ }^{a}$ significant at $1 \%$. Shock: agricultural commodity shock as defined in equation (1) in columns (1) and (2); exposure to crises in columns (3) and (4) as defined in equation (2); ; AGOA dummy in columns (5) and (6). 1 in equation (1) in columns (1) and (2); exposure to crises in columns (3) and (4)
distance to closest seaport relative to maximum distance, computed by country. 


\subsection{Additional figures}

Figure 2: Number of locations with at least one conflict, by year

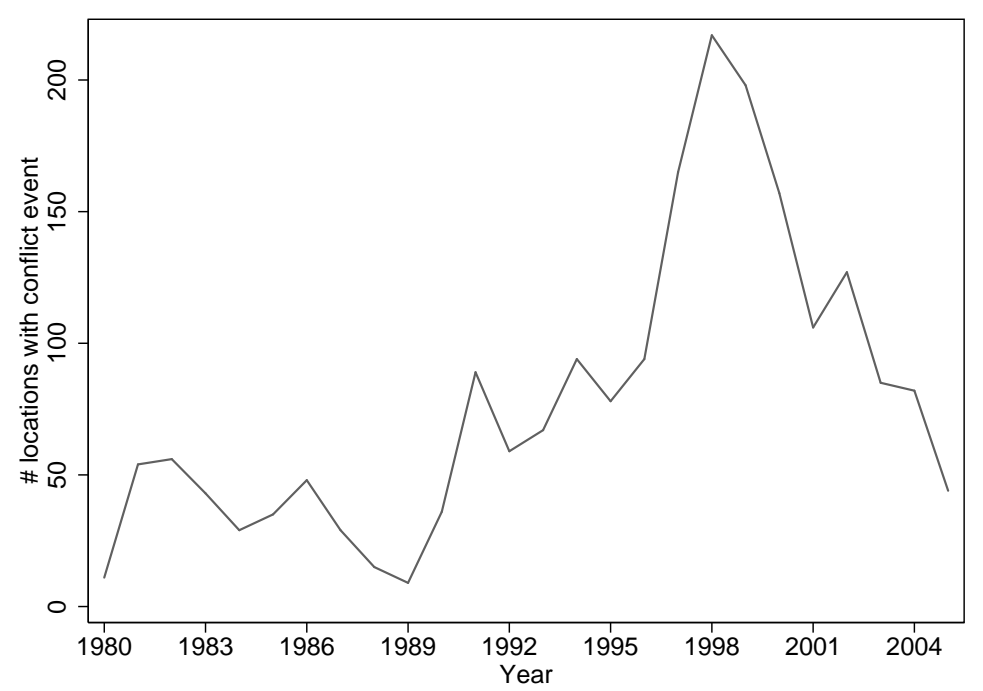


(a) Angola

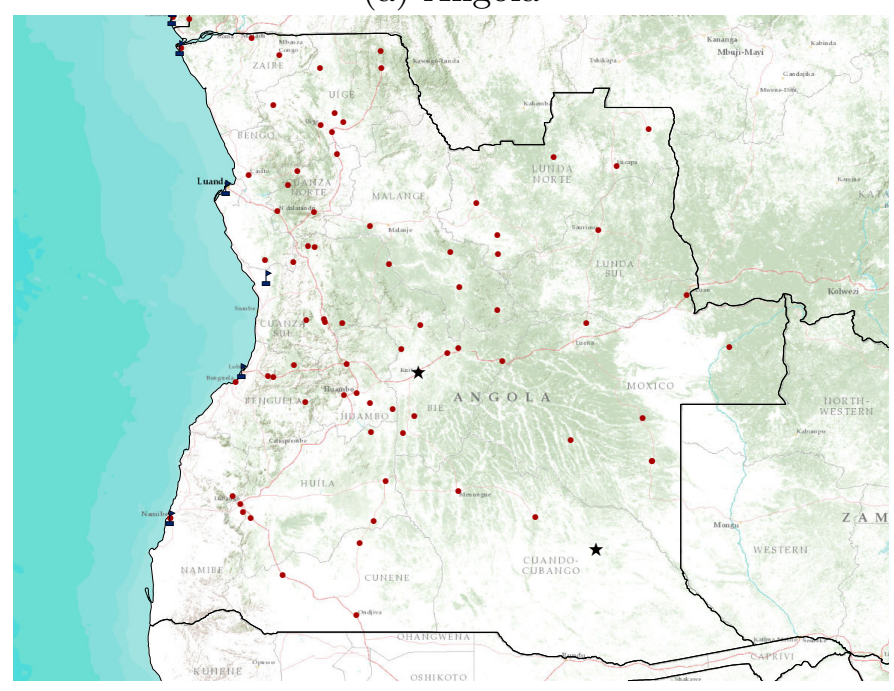

(c) Congo

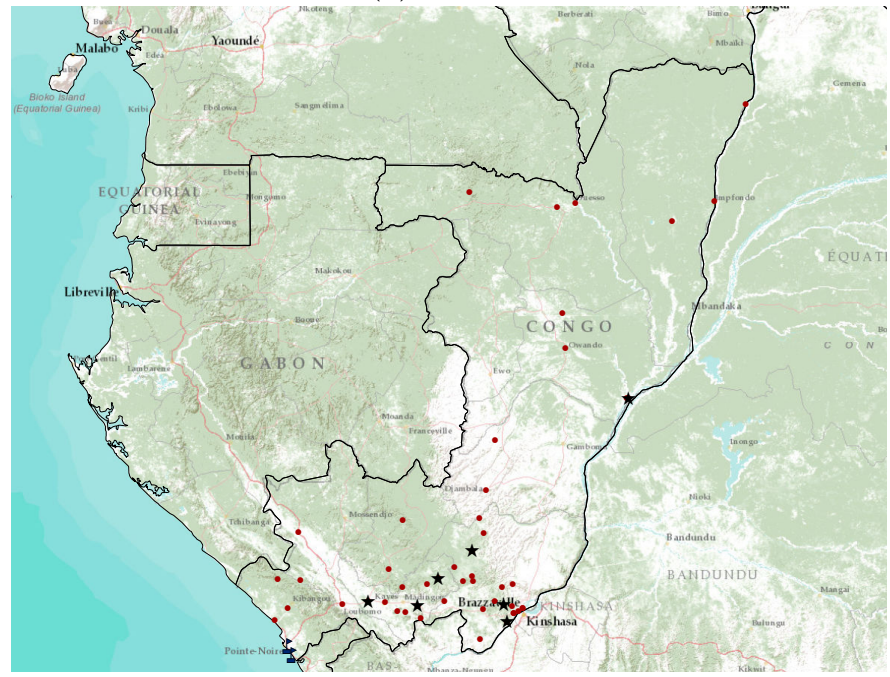

(b) Burundi

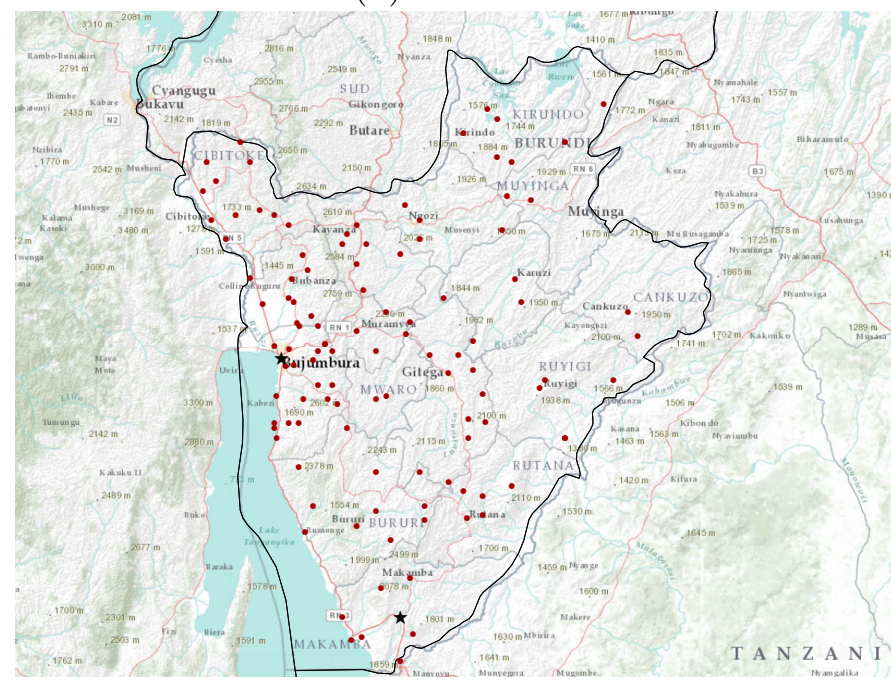

(d) Democratic Republic Congo

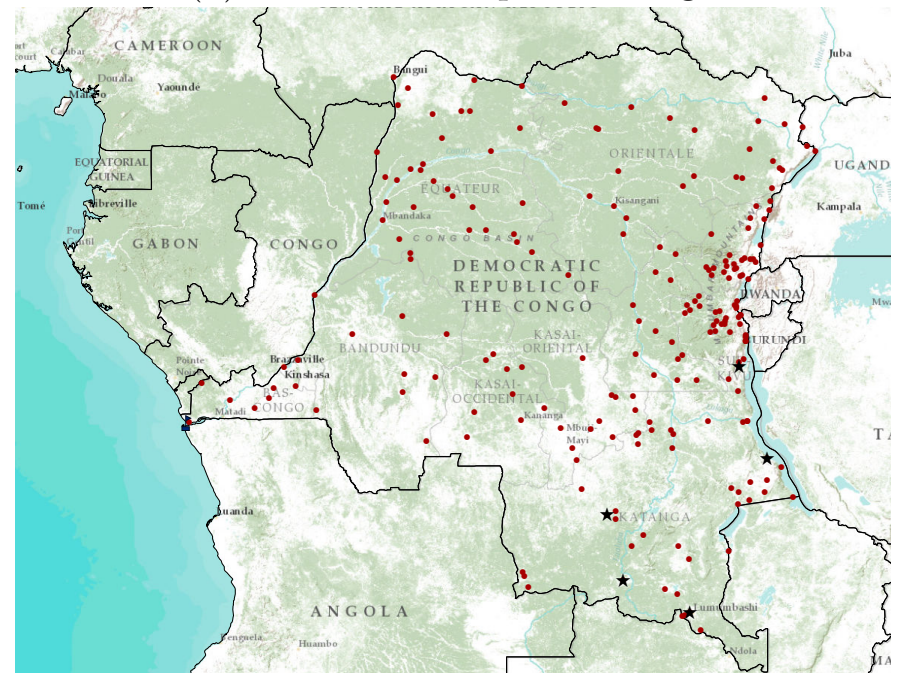

These maps represent the location of conflict events over 1980 - 2005 period (ACLED data). Dots represent conflict events, stars represent the location of the outbreak of conflict. Flags indicates the location of the major seaports of the country. 
Figure 4: Conflict locations (2)

(e) Liberia

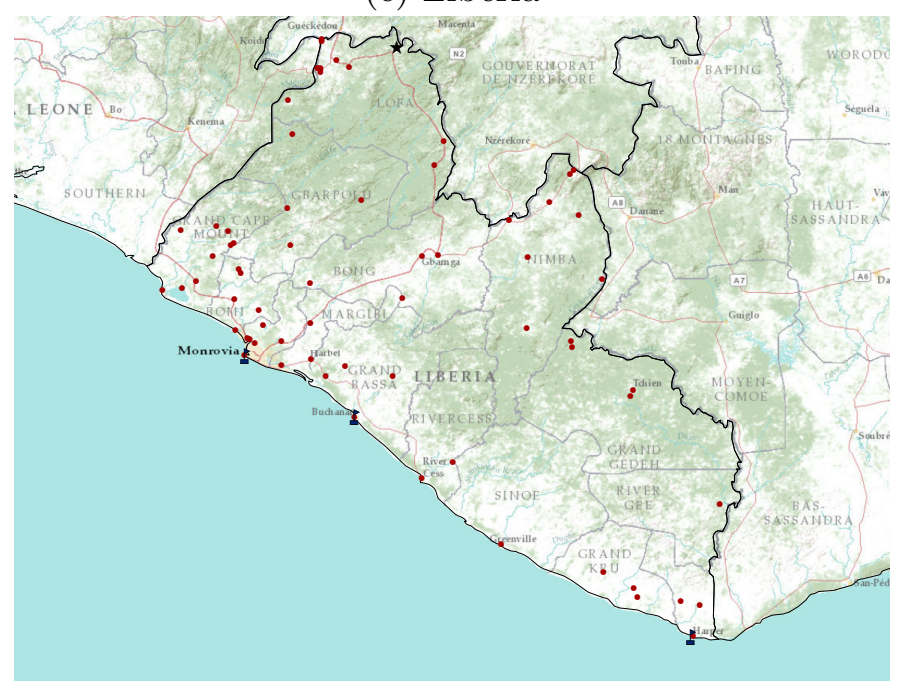

(g) Sudan

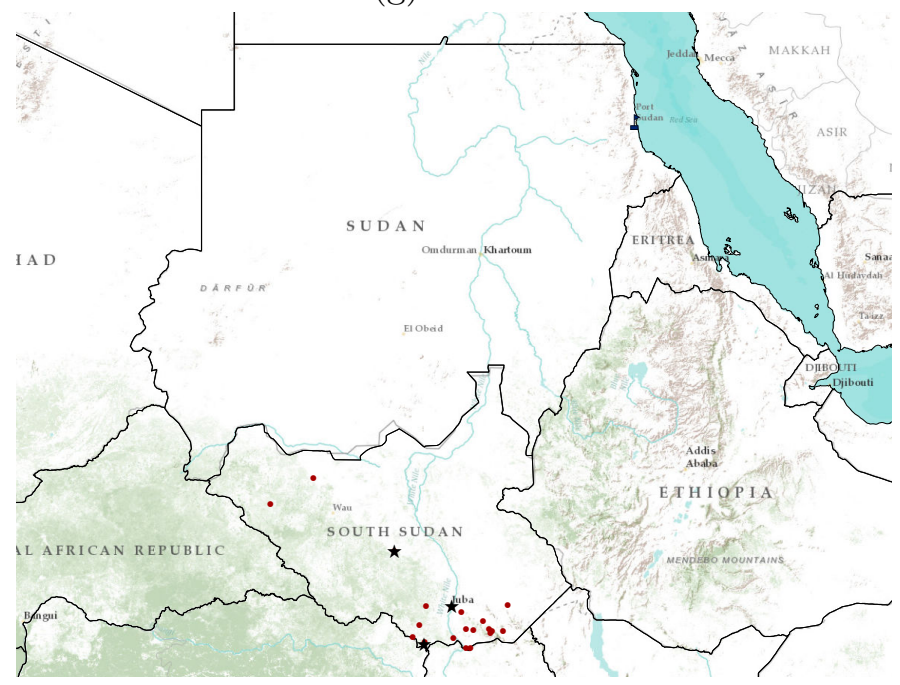

(f) Sierra Leone

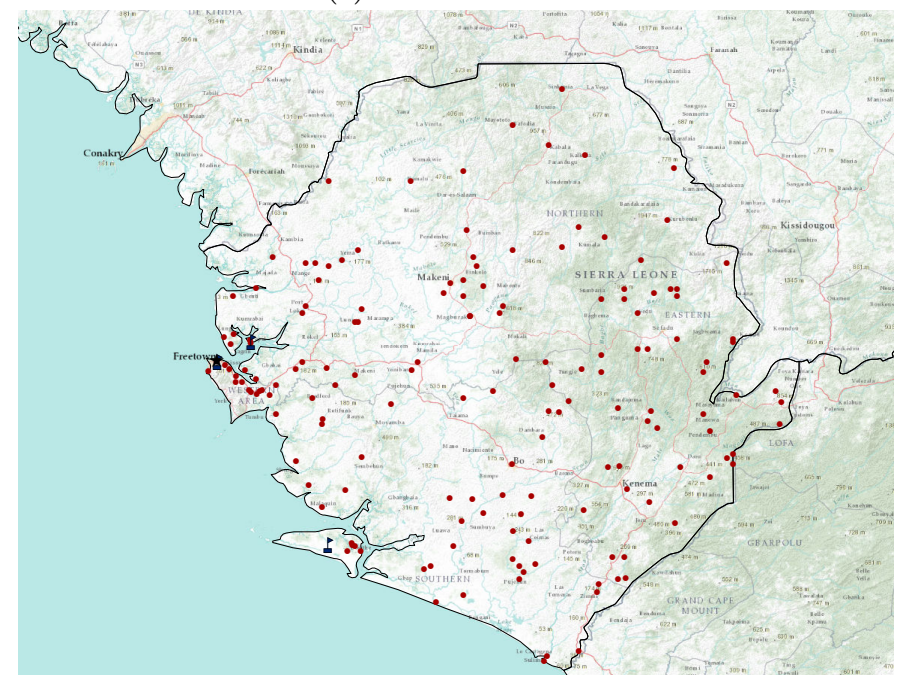

(h) Uganda

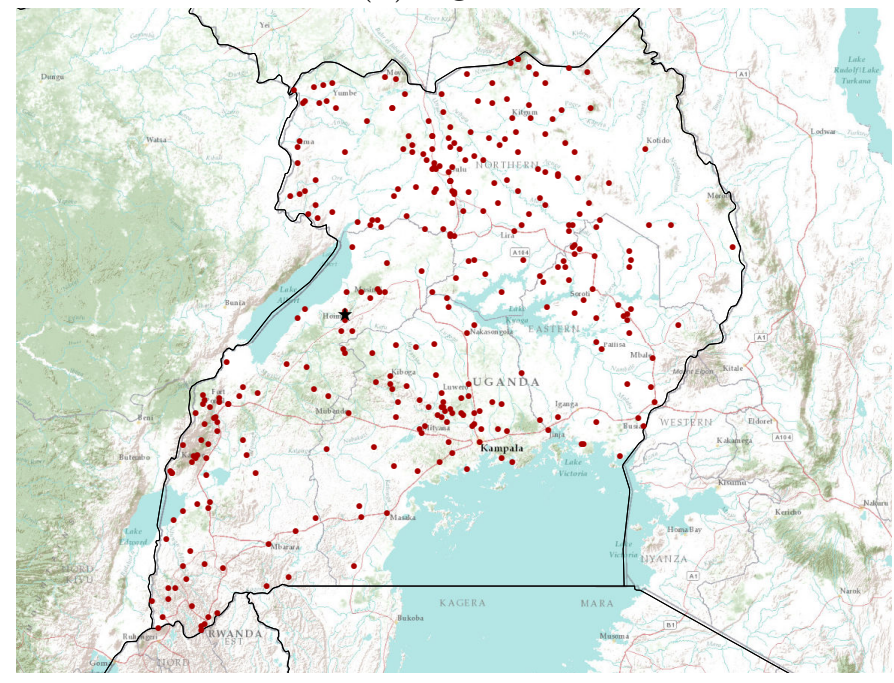

These maps represent the location of conflict events over 1980 - 2005 period (ACLED data). Dots represent conflict events, stars represent the location of the outbreak of conflict. Flags indicates the location of the major seaports of the country. 